\title{
Putting the Practice Into Theory
}

\author{
Eric J. Miller*
}

\section{INTRODUCTION}

The police's role in criminal procedure has changed dramatically since the Warren Court constitutionalized criminal procedure in the 1950s and 1960s. While law and legal scholarship have changed dramatically as well, they have failed to keep up with real-world transformations that have seen law-based (and, in particular, court-centered) regulation become an increasingly marginal aspect of police regulation in particular, and the criminal justice system in general.

The reason is easy to identify: criminal procedure doctrine has traditionally been overwhelmingly concerned with an emphasis on the Constitution. Its goal has been to protect individual rights by justifying or challenging the judicial authority to hold the police accountable. ' Consequently, rights have dominated our understanding of what criminal procedure is all about. To the extent that criminal procedure doctrine attempts to justify judicial intervention in the process of policing, it does so by establishing the rights of individual citizens to be free from governmental interference. ${ }^{2}$

The "starkness" of the rights-based criminal procedure debate has constrained our ability to both analyze and improve the criminal justice process. ${ }^{3}$ For example, Herbert Packer's famous two models of due process and crime control ${ }^{4}$ have locked most doctrinal discussion into a dispute over the nature of political and moral rights, rather than the process of criminal justice regulation and its relation to crime and criminology. In his devastating critique of contemporary criminal theory, Criminal Law, Criminology, and the Small World of Legal Scholars, Robert

* Assistant Professor of Law, Saint Louis University School of Law. My thanks for their comments on earlier drafts of this paper to William D. Araiza, Christine A. Klein, Elizabeth Mertz, Fabio Arcila, Jr., John Mikhail, David Sklansky, Robert Weisberg, David Harris, Matthew T. Bodie, Frederic M. Bloom, Anders Walker, and Sam Jordan. I have received excellent research help from Courtney Goodwin and Amy K. Davis.

1 See, e.g., Yale Kamisar, In Defense of the Search and Seizure Exclusionary Rule, 26 HARV. J.L. \& PUB. POL'Y 119, 124 (2003) [hereinafter Kamisar, Defense] (discussing failure to regulate police prior to Court's rights revolution); Yale Kamisar, Remembering the "Old World" of Criminal Procedure: A Reply to Professor Grano, 23 U. Mich. J.L. REFORM 537, 559-60 (1990).

2 See, e.g., Herbert L. Packer, Two Models of the Criminal Process, 113 U. PA. L. REV. 1, 14-23 (1964) (discussing due process understanding of criminal procedure).

3 Robert Weisberg, Criminal Law, Criminology, and the Small World of Legal Scholars, 63 U. Colo. L. REv. 521, 532 (1992) (describing the current debate as dominated by a battle between competing rights and utilities).

4 See, e.g., Packer, supra note 2, at 9-23 (suggesting there are two styles of criminal procedure-due process and crime control). 
Weisberg suggested that, led down this relatively narrow path of abstract theorizing, criminal procedure scholarship has reached a dead end. "People have been searching for something else imaginative to say ever since."

It turns out, however, that while Weisberg was correct about the rights debate, he was wrong about the regulatory one. Since the late 1960s and early 1970s, scholars have pointed out inefficiencies in the judicial regulation of the criminal justice system and prescribed a variety of solutions. For example, Anthony Amsterdam identified and critiqued the judiciary's relative incompetence as a scrutinizing or disciplinary institution: the judiciary "lacks the sort of supervisory power over the practices of the police that is possessed by the chief of police or the district attorney." For Amsterdam, the issue is not the judicial right to intervene in policing, but whether the judicial branch is capable of regulating the police, and how they ought to do so. Any discussion of the appropriate forms of regulation can (and must) exist separate from the rights debate and focus instead upon claims about the actual (descriptive) and appropriate (prescriptive) structure of police administration. These questions of structure are, in turn, the stuff of criminology and social science.

David Sklansky's Policing and Democracy provides a useful counterweight to Weisberg's criminological pessimism. ${ }^{7}$ Sklansky seeks to demonstrate the ways in which the development of criminal procedure doctrine has been strongly influenced by democratic theory, yet has received little "systemic" attention from courts or commentators. ${ }^{8}$ This sort of theory is expressly concerned with the place of policing in a democratic state and the interrelation of the various regulatory institutions that govern policing. ${ }^{9}$ Criminology has, Sklansky agrees, permeated the judicial and academic consciousness through a "jurisprudence of policing and academic commentary on that jurisprudence," one that has been influenced by (and in its turn, influenced) "studies of the police carried out by social scientists. ...,10 There is, in other words, a tradition within the judicial and academic discussion of criminal procedure that tracks and sporadically engages with criminology and social science, one that seeks to understand, among other things, the "social

5 Weisberg, supra note 3, at 532 . One of my many disagreements with Weisberg, however, is that this dead end is the fault of "analytic jurisprudence." Compare id. at 527-28 (I consider myself a dabbler in just the sort of H.L.A. Hart-influenced jurisprudence Weisberg attacks), with Eric J. Miller, Judicial Preference, 44 Hous. L. REV. 1275 passim (2008). The dead end, I shall suggest, results from confusing rights with regulation.

6 Anthony G. Amsterdam, The Supreme Court and the Rights of Suspects in Criminal Cases, 45 N.Y.U. L. Rev. 785, 786 (1970).

7 David Alan Sklansky, Police and Democracy, 103 MiCH. L. REv. 1699 (2005).

8 Id. at 1703.

9 As Sklansky points out, the question of what democracy is, and its relation to the accountability and social control of governmental institutions, was and remains problematic. $I d$. at 1819 (noting that there has been little attention to the question of accountability of the police).

10 Id. at 1704. 
relations ... among police officers, and relations between police officers and the wider society."

My claim is that both Weisberg and Sklansky are right about the status of criminology in criminal procedure. Criminology has been relegated to a subsidiary position by the rights debate, but it has nonetheless carved out an important space in criminal procedure when the conversation turns from the nature of rights to the possibility of regulation. The regulatory debate, which is relatively nonconstitutional in nature, has been proceeding somewhat under the radar for almost as long, or perhaps longer, than the rights debate. ${ }^{12}$ One reason for the relative disregard for regulation as an independent subject is that focusing on rights surreptitiously elides (or is mistakenly taken to solve) the regulatory issues.

I claim that modern criminal procedure, or especially at the Supreme Court level, rests upon a variety of untested regulatory assumptions about the ways in which the police do and ought to interact with the public. These regulatory assumptions depend upon underlying models of police administration that often determine the outcome of cases. Nonetheless, these assumptions are fictional, meaning that they lack any basis in descriptive criminology or social science. Yet they control the development of judicial and academic understandings of what policing is and ought to be about in our modern, fragmented, pluralist democracy. My prescription, at least for the academy, is that we should start examining the criminological evidence to determine whether and how it might support or undermine the Court's social science speculations. ${ }^{13}$

Constitutional law has always been somewhat marginal in the regulatory universe. Executive branch officials control most of what happens in the criminal justice system. They act according to departmental policies or institutional practices. Though they might have one eye on the courts and the Constitution, they are more concerned with norms of professional ethics or institutional organization. Attending to regulation tilts criminal procedure off its court-centered axis and reminds us just how ineffective we legal scholars may be in setting its terms. $^{14}$

\section{Id. at 1732.}

12 Sklansky, for example, dates its onset to 1953, and a pair of articles by William Westley and Jerome Hall. See Sklansky, supra note 7, at 1731.

13 I realize I am not alone in this. See, e.g., Tracey L. Meares \& Bernard E. Harcourt, Foreword: Transparent Adjudication and Social Science Research in Constitutional Criminal Procedure, 90 J. CRIM. L. \& CRIMINOLOGY 733 (2000). As will be made explicit, I differ from Meares and Harcourt over the place in legal argumentation that social science and criminology can influence the Court.

14 As lawyers, we tend to focus almost exclusively on that part relating to criminal investigation rather than the other police activities that in fact take up the majority of their time. There are exceptions. The sociological approach to criminal procedure provides many of them. See, e.g., Bernard E. Harcourt, Policing L.A.'s Skid Row: Crime and Real Estate Redevelopment in Downtown Los Angeles [An Experiment in Real Time], 2005 U. CHI. LEGAL F. 325; Bernard E. Harcourt, After the "Social Meaning Turn": Implications for Research Design and Methods of Proof in Contemporary Criminal Law Policy Analysis, 34 LAW \& SoC'Y REV. 179 (2000); Debra 
My goal in what follows is to trace some of the ways in which criminal procedure doctrine engages with criminology, particularly in its more hermeneutic form. As a starting point, I consider Robert Weisberg's and David Sklansky's very different but deeply thoughtful discussions of the relation between criminal procedure, on the one hand, and criminology and social science, more generally, on the other. In Section II, I develop that relation by demonstrating that rightsbased criminal procedure often presumes a particular regulatory style. From a rights perspective, regulation is often presented as a byproduct of judicial and constitutional accountability. The Court has, however, developed a set of regulatory methodologies through which to limit police activity that must be justified independent of the rights-based reasons for judicial intervention. In Section III, I develop two regulatory reactions to this jurisprudence, both of which directly engages with or assumes a particular regulatory understanding of the police. In Section IV, I discuss two cases United States v. Leon, ${ }^{15}$ and Hudson v. Michigan, ${ }^{16}$ to illustrate the ways in which the Court does, and does not, respond to criminological and social science data in choosing among the available regulatory styles.

\section{REgULATORY CRIMINAL PROCEDURE}

My critical review of the interaction of criminology and criminal procedure begins with Robert Weisberg's charge that rights-based criminal procedure has become "boring," even though it remains the only game in town." Weisberg expresses an understandable frustration with a debate framed in terms of different stages of judicial policy associated with successive Courts (Warren, Burger, Rehnquist) or a lurch between rules and standards, ${ }^{18}$ which, in the criminal procedure context, is the debate over bright lines versus case-by-case adjudication, or categorical versus individualized norms. ${ }^{19}$ As he puts it: "The doctrine has been

Livingston, The Unfulfilled Promise of Citizen Review, 1 OHIO ST. J. CRIM. L. 653 (2004) [hereinafter Livingston, Citizen Review]; Debra Livingston, Police, Community Caretaking, and the Fourth Amendment, 1998 U. CHI. LEGAL F. 261; Tracey L. Meares, Norms, Legitimacy and Law Enforcement, 79 OR. L. REV. 391 (2000); Tracey L. Meares \& Dan M. Kahan, Law and (Norms Of) Order in the Inner City, 32 LAw \& SoC'Y REV. 805 (1998); Paul H. Robinson, Why Does the Criminal Law Care What the Layperson Thinks is Just? Coercive Versus Normative Crime Control, 86 VA. L. REV. 1839 (2000).

15 United States v. Leon, 468 U.S. 897, 919-23 (1984).

16 Hudson v. Michigan, 547 U.S. 586 (2006).

17 Weisberg, supra note 3, at 530.

18 See California v. Acevedo, 500 U.S. 565, 582 (1991) (Scalia, J., concurring) ("[O]ur jurisprudence [has] lurched back and forth between imposing a categorical warrant requirement and looking to reasonableness alone.").

19 The literature on different courts and bright-line rules versus case-by-case standards is vast. For a flavor, see, e.g., Yale Kamisar, The Warren Court (Was It Really So Defense-Minded?), the Burger Court (Is It Really So Prosecution-Oriented?), and Police Investigatory Practices, in THE Burger Court: The Counter-Revolution That WasN'T 62 (Vincent Blasi ed., 1983); Albert W. 
typically cast by the scholars as a political melodrama with a scripted dramatic story[line] . . . of expanded constitutional protection . . . followed by . . . retrenchment ... . The process leads to mechanical outcome counting and evaluation ...., ${ }^{20}$ Legal scholars, he believes, too often ignore social science data except to the extent it supports their constitutional arguments. We in the legal academy have failed to engage in a dialogue with law enforcement and criminal justice professionals, social scientists and criminologists, preferring instead to impose some idealized set of norms on the police. Courts, unfortunately, have done the same, periodically dabbling in the social science literature to support their own regulatory prescriptions. ${ }^{21}$

While Weisberg may be right about the rights debate, ${ }^{22}$ it is not the only game in town. ${ }^{23}$ Existing alongside the debate over political and legal rights is a parallel discussion over how to regulate the police. In emphasizing regulation, I shall suggest that Weisberg is correct in asserting that the past half-century of liberal constitutionalism has largely ignored the structure or nature of policing, not to mention underlying issues of crime and criminology. ${ }^{24}$ " $[\mathrm{R}]$ ights-oriented

Alschuler, Failed Pragmatism: Reflections on the Burger Court, 100 HaRv. L. ReV. 1436 (1987); Peter Arenella, Rethinking the Functions of Criminal Procedure: The Warren and Burger Courts Competing Ideologies, 72 Geo. L.J. 185 (1983); Craig M. Bradley, Two Models of the Fourth Amendment, 83 Mich. L. Rev. 1468 (1985); Donald A. Dripps, The Fourth Amendment and the Fallacy of Composition: Determinacy Versus Legitimacy in a Regime of Bright-Line Rules, 74 Miss. L.J. 341 (2004); Donald A. Dripps, Beyond the Warren Court and Its Conservative Critics: Toward a Unified Theory of Constitutional Criminal Procedure, 23 U. MiCH. J.L. REFORM 591 (1990); Jerold H. Israel, Criminal Procedure, the Burger Court, and the Legacy of the Warren Court, 75 MicH. L. REV. 1319 (1977); Wayne R. LaFave, Controlling Discretion by Administrative Regulations: The Use, Misuse, and Nonuse of Police Rules and Policies in Fourth Amendment Adjudication, $89 \mathrm{MICH}$. L. REv. 442 (1990) [hereinafter LaFave, Controlling Discretion]; Wayne R. LaFave, "Case-By-Case Adjudication" Versus "Standardized Procedures": The Robinson Dilemma, 1974 SUP. CT. REV. 127 [hereinafter LaFave, The Robinson Dilemma]; Stephen A. Saltzburg, Foreword: The Flow and Ebb of Constitutional Criminal Procedure in the Warren and Burger Courts, 69 GEO. L.J. 151 (1980); Silas J. Wasserstrom, The Court's Turn Toward a General Reasonableness Interpretation of The Fourth Amendment, 27 AM. CRIM. L. REV. 119 (1989).

20 Weisberg, supra note 3, at 530.

21 See Meares \& Harcourt, supra note 13.

22 Sklansky's excellent article suggests that Weisberg has read the academic literature with a somewhat jaundiced eye. See Sklansky, supra note 7, at 1731-48 (discussing the influence of democratic theory and a criminology of policing on the court and academic scholarship in the 1950s and 1960s).

${ }^{23}$ I do not think it was the only way of thinking about criminal procedure even in 1992, when Weisberg wrote Criminal Law, Criminology, and the Small World of Legal Scholars. Weisberg, supra note 3.

24 The Court, on occasion, has suggested that regulation poses a distinct and significant challenge, as Weisberg recognizes, see id. at 532-33 (discussing Chief Justice Warren's recognition that the judiciary can only regulate a small amount of police activity) (citing Terry v. Ohio, 392 U.S. 1, 13-14 (1968)), and Robert Weisberg, Foreword: Criminal Procedure Doctrine: Some Versions of the Skeptical, 76 J. CRIM. L. \& CRIMINOLOGY 832, 843-44 (1985), but it also periodically dabbles in 
liberal[s]"25 are not interested in understanding the nature of crime control. Their point is not to engage in a bilateral discussion with law enforcement but rather to encourage or if necessary force the police to adopt constitutionally mandated norms of conduct.

If, however, regulation is the name of the game, then the academic or judicial use of quantitative sociological data to measure the scope of constitutional rights provides the wrong solution to the wrong problem. Instead of focusing on abstract conceptions of rights, we should look to criminology, particularly the sort of qualitative criminology that directly engages the regulatory sphere. Qualitative social science research seeks to produce a thick, or "hermeneutic," picture of the structure and self-understandings of the major agents and institutions engaged in crime control. It exposes the ways in which different institutions regulate the police and enables the judiciary and the academy to evaluate different institution's effectiveness in scrutinizing and controlling police conduct, as well as uncovering the ways these institutions promote particular styles and goals of policing.

\section{A. Criminology and Regulation}

In his 1992 article Criminal Law, Criminology, and the Small World of Legal Scholars, Weisberg's central complaint was that criminal procedure scholarship failed to engage with criminology or social science studies. He argued that "criminal law scholarship [had not yet] . . . reach[ed] the point of confounding itself with the complexities of inter-disciplinary explanation we associate with legal modernism," and asked the wrong questions of criminology. ${ }^{27}$ By contrast, David Sklansky, in his 2005 article on Police and Democracy, suggests that the scholarship has been more or less obsessed with criminology. ${ }^{28}$

One reason for their different perspectives may be the plethora of articles published in the intervening decade or so filling the criminology gap. ${ }^{29}$ But that does not explain why Sklansky considers that criminal procedure engaged with both criminology and penal modernism in the 1980 s and $1990 \mathrm{~s}^{30}$ Their difference

the social science literature to support its regulatory moves. See generally Meares \& Harcourt, supra note 13 .

25 Meares \& Harcourt, supra note 13, at 741 .

26 Weisberg, supra note 3, at 522.

27 Id. at 529-30.

28 See generally Sklansky, supra note 7.

29 Both, for example, discuss the turn to social norms that seeks to engage with social science and criminological data. See, e.g., Robert Weisberg, Norms and Criminal Law, and the Norms of Criminal Law Scholarship, 93 J. CRIM. L. \& CRIMINOLOGY 467 (2003); Sklansky, supra note 7, at 1781-1802 (discussing work of social norms theorists Dan Kahan and Tracey Meares).

${ }^{30}$ See Sklansky, supra note 7 , at 1728-53 (discussing impact of modernity on criminal procedure theory). 
is perhaps over the style of criminal procedure and its relation to criminology: that the relation is superficial rather than deep, implied rather than express, tangential rather than direct. Accordingly, Weisberg wrings his hands over the legal academy's "predisposed disdain for the intellectual power of sociology," Sklansky celebrates a tradition of indirect connections in which ideas interrelate, "resonate and fit together." ... require[s] us to take account of trends in social science about the police, if for no other reason than that the paths of influence have often run through that work.",33

Both, however, agree over the need for a more precise and hermeneutic criminology, one that elucidates the institutional structure of the police and policing. ${ }^{34}$ Hermeneutic criminology is concerned with charting the attitudes and self-understandings of the major players in the criminal justice system, including criminals and police. It seeks, in part, to understand how their behavior comports with public, official rules of social governance. This is the sort of criminology Sklansky identifies as concerned with understanding the police as a distinct "social and occupational group." 35 More broadly, there is a tradition of criminology and penology, beginning with Emile Durkheim and achieving its most popular modern form in the work of Michel Foucault, that seeks a hermeneutic account of crime and policing. ${ }^{36}$ The point is not simply to generate data about the effectiveness of various policy initiatives, but to place policy in a cultural context and evaluate the meanings of various types of conduct for particular social systems. ${ }^{37}$

There is far more that criminal procedure can learn from criminology than the empirical impact of certain norms on police or public conduct. ${ }^{38}$ Rather than operating only as a consequentialist measure of legislative or judicial efficacy, ${ }^{39}$ criminology can help us understand the variety of criminal justice "systems" that

31 Weisberg, supra note 3 , at 527.

32 Sklansky, supra note 7, at 1728 (quoting David Nelkin, Using the Concept of Legal Culture, 29 Austl. J. Legal PhiL. 1, 9 (2004)).

33 Id. at 1705

34 See Sklansky, supra note 7, at 1753, 1799-1803 (bemoaning de-emphasis on institutional structure in both criminological and criminal procedure scholarship); Weisberg, supra note 3, at 564, 568 (discussing "David Garland's refreshingly sensible argument for how sociological analysis and ethnography can enhance the study of criminal justice.").

35 Sklansky, supra note 7, at 1732 (quoting WILLIAM A. WESTLEY, VIOLENCE AND THE POLICE: A SOCIOLOGICAL STUDY OF LAW, CUSTOM, AND MORALITY 8 (1970)) (quotation marks omitted).

36 See, e.g., David Garland, Punishment and Modern Society: A Study In Social THEORY 286 (1990). See also Weisberg, supra note 29, at 590-91 (citing GARLAND, supra at 76-77; EMILE DuRKheim, The Division of LABOR IN SOCIETY (1893)).

37 See GARLAND, supra note 36, at 213-48 (discussing interrelation between culture, crime, and crime control).

38 This essentially states my difference with Meares and Harcourt's excellent article. Meares \& Harcourt, supra note 13 .

39 See, e.g., Weisberg, supra note 3 , at 530-32. 
operate outside and often in opposition to the courts. A major goal of incorporating social science research into the study of constitutional criminal procedure, then, is to put both the constitution, and the police, in their place (wherever that is) as agents of social control and social regulation. ${ }^{40}$

\section{Regulatory Strategies}

In the criminal justice system, the justification of regulation is descriptively and normatively independent of the rights at stake. Although courts depend upon rights-based authorization to permit judicial intervention, the rights at issue do not mandate any particular regulatory style. Regulation is premised upon concepts of control and supervision: accordingly, a regulatory prioritizing concerns itself primarily with rules delineating the nature and scope of executive competence and governmental authority to regulate executive police activity. Judicial authority to supervise and control executive investigative activity may be triggered, but need not be exhausted, by a concern to protect individual rights. Accordingly, the central concern of a regulatory approach is to identify the norms used to demarcate an institution's power to evaluate and delimit the bounds of police investigatory activity.

Regulatory justifications typically address four questions: what is the purpose of a given regulatory strategy; what is the appropriate source of regulation; at what stage of the criminal investigation should that source intervene; and how uniform the norms produced should be. Modern criminal procedure demands that the answer to these questions turn upon some pragmatic or hermeneutic understanding of how constitutional norms affect police conduct.

In its simplest form, regulation corresponds to the different stages at which scrutiny of criminal investigation can occur: beginning, middle, and end. Frontend regulation requires pre-authorization of future conduct by asking permission to act; the middle sort of regulation mandates contemporaneous monitoring of ongoing conduct; and back-end regulation utilizes retrospective review of past conduct by comparison with some set of norms or regulations.

At each stage, the source of regulation can engage in more or less scrutiny depending upon whether it undertakes a more or less individualized evaluation of law-enforcement activity. Accordingly, scrutiny can be either categorical or

40 Some recent examples of this movement at the pedagogical level, emphasizing empiricism at the expense of or in addition to, case study, are: RONALD JAY ALLEN ET AL., COMPREHENSIVE Criminal Procedure (2001); Marc L. Miller \& Ronald F. Wright, Criminal Procedures: Cases, Statutes, and Executive Materials (2001); Christopher Slobogin, Criminal Procedure: Regulation of POlice INVEstigation: Legal, Historical, EMPIRICAL, AND COMPARATIVE MATERIALS (1998). For some perceptive reviews of these books, see Stephanos Bibas, The Real-World Shift In Criminal Procedure, 93 J. CRIM. L. \& CRIMINOLOGY 789 (2003) (book review); Robert Weisberg, A New Legal Realism for Criminal Procedure, 49 BuFf. L. REV. 909 (2001) (book review); Daniel Yeager, Searches, Seizures, Confessions, and Some Thoughts on Criminal Procedure: Regulation of Police Investigation-Legal, Historical, Empirical, and Comparative Materials, 23 FLA. ST. U. L. REv. 1043 (1996) (book review). 
individualized. ${ }^{41}$ Categorical regulation provides greater uniformity over the run of cases, whereas individualized regulation allows for more disparity. Regulation may, but need not, require the imposition of a sanction for failure to act in conformity with the relevant directive. In the law of criminal investigation, the central sanction is suppression of unlawfully obtained evidence.

Each of the different methods of regulation can be combined so that, for example, a wire tap may require pre-authorization by means of a warrant, followed by continuous monitoring by a judge and, if the validity of the search is challenged, some retrospective review demonstrating that the police adhered to the various legislative, judicial, or constitutional norms governing wire-taps, or properly exercised their judgment when conducting the surveillance. ${ }^{42}$

Once we move to regulation, then, it becomes legitimate to wonder about the purpose of a given regulatory strategy. Particular regulatory regimes may seek to provide uniform standards to regularize conduct or permit individualized judgments to encourage experimentalism. They may promote some form of independent review or self-regulation. Different strategies may be administered by a variety of different sources: legislative, judicial, executive, citizen review boards, ${ }^{43}$ as well as through consent from the target of law-enforcement conduct. ${ }^{44}$ As both Weisberg and Sklansky argue in their different ways, debates over the appropriate source, stage, and style of regulation implicate debates about the nature of democracy and the role of the police in American society. In turn, these regulatory debates explicitly (in the social science and more recent criminal procedure literature) or implicitly (in some traditional criminal procedure scholarship) rest upon criminological characterizations of policing and crime.

\section{Rights-Oriented Liberalism and Judicial Pre-Authorization}

Weisberg suggests that the Warren Court, and the criminal justice scholarship spawned to justify or challenge its rights revolution, has failed to confront criminology, and in particular, social science data. But even if Weisberg is right about our relative failure to become more interdisciplinary-and criminal procedure has become much more interdisciplinary since he wrote in $1992^{45}$ criminal procedure has always been indirectly influenced, even if it has not directly

41 Categorical scrutiny is thus "categorical" in the same way "categorical balancing" is. See Silas J. Wasserstrom, \& Louis Michael Seidman, The Fourth Amendment as Constitutional Theory, 77 GEO L.J. 19, 48 (1988) (describing categorical balancing test).

42 See Clifford S. Fishman, Interception of Communications in Exigent Circumstances: The Fourth Amendment, Federal Legislation, and the United States Department of Justice, 22 GA. L. REV. 1, 23-24 (1987).

43 See, e.g., Livingston, Citizen Review, supra note 14.

44 See, e.g., Miranda v. Arizona, 384 U.S. 436 (1966).

45 Much to his chagrin. See generally Weisberg, supra note 29 (critiquing the social norms theorists, and in particular criminal procedure scholars Dan Kahan and Tracey Meares, as lacking sufficient social science rigor). 
engaged with, social science literature on policing and crime. This influence, Sklansky argues, comes from criminal procedure and criminology's tangential relation with democratic theory.

Sklansky, among others, suggests that the Warren Court embraced a specific mode of regulation, one based in a particular, "pluralist" form of democratic theory. ${ }^{46}$ For Sklansky, the Warren Court embraced a particular "conception of the police as a discrete and unified group, alienated from mainstream society, ${ }^{, 47}$ a conception that envisaged "the problem of police discretion" as the major regulatory challenge. ${ }^{48}$ Accordingly, the goal was to inculcate or enforce a respect for the rule of law by demanding that police activity proceed only with "'advance judicial approval' in the form of a warrant." ${ }^{, 49}$ This "judicial prescreening",50 through the warrant "was perhaps the Warren Court's most characteristic approach to the police." 51

In what follows, I shall suggest that Sklansky is right about the regulatory justifications for the warrant: it was a means of legitimizing police conduct (purpose) through authorization by an institution "independent of the police"s52 (source) that operated at the front-end of the investigatory process (stage). It is also worth adding that this sort of scrutiny was, as conceived by the Warren Court, quite intense, though it would subsequently be watered down.

But Sklansky perhaps overstates the relation between this form of regulation and liberalism in general. This form of regulation (independent pre-authorization) is not inherently liberal, nor animated by the sort of police lawlessness that liberals identified with the police: "[ $t]$ he notion that the police have a distinctive mentality-rigid, insecure, inclined toward violence, hostile to anyone 'different' - [that] became widespread . . . particularly on the Left." ${ }^{.53}$ Instead, I shall suggest, this form of regulation is available for any judge seeking to justify independent authorization of police activity. Conservatives thus embrace this form of regulation on occasion, not because they fear police lawlessness, ${ }^{54}$ but because, in a variety of circumstances, independent pre-authorization is justified where police self-regulation becomes an issue of public or judicial confidence. Judicial pre-screening, as with other forms of independent review, responds to a pluralism).

46 Sklansky, supra note 7, at 1728-53 (discussing relation between policing and democratic

47

48

Id. at 1738 .

50 Id.

$51 \quad$ ld. at 1737.

52 Id. at 1738 (emphasis omitted).

$53 \quad I d$. at 1733 .

54 This is the worry about "ferreting out crime" present in the oft-cited quotation of Johnson v. United States, 333 U.S. 10, 14 (1948). 
criminological assumption about the nature and structure of the police as an institution, not a political assumption about policing as valuable or valueless.

Another difference with Sklansky I shall also suggest is that there are two styles associated with the sort of rights-based liberalism emanating from the Warren Court, which, although they differ in the sources and stages of investigation to which they apply, share a common purpose or interest in regulating the police. One is, of course, the warrant. The other is consent. In what follows, I briefly consider the purpose, source, stage, and uniformity of each. Since the features distinguishing warrants from consent are the sources and stages of regulation, I spend most time on these aspects of the regulatory regimes.

\section{i. Purpose}

The purpose of both the warrant requirement and consent is to legitimize and restrict police investigatory activity by providing an objective, independent second opinion before (and, for consent, while) the police engage in investigative conduct. Independent review provides an open, fair, democratic process, as well as protecting vulnerable interests and securing uniform official practices. The warrant, for example, operates as both judicial guarantee that the investigative activity is constitutional, and as permission to search or seize granted according to consistent, national standards.

In those circumstances when we want an external check on police conduct, independent review provides an appropriate form of regulation. Officials do not bring their own prejudices into the process of regulation, but enforce the law as directed by impartial others. Independent review is thus both a preventative device, limiting or eliminating the institutional and individual autonomy of the police, ${ }^{55}$ as well as a democracy-enhancing one, providing a neutral or adversarial authority to justify police actions. Accordingly, this style of regulation is appropriate whenever the worry is that the risks involved in self-regulation are too problematic. $^{56}$

\section{ii. Source}

Warrants under the Fourth Amendment, and consent under the Fourth and Fifth Amendments, do, of course, have different sources granting independent authorization to engage in searches, seizures, and interrogation: the judge in the

55 The classic prophylactic procedural device, the warrant, "is calculated to prevent, not to repair." Elkins v. United States, 364 U.S. 206, 217 (1960).

56 The more direct worry is, in the words of Justice Stevens, that the Fourth Amendment would become "an unenforced honor code that the police may follow in their discretion." United States v. Leon, 468 U.S. 897, 978 (1984) (Stevens, J., dissenting). See also Kamisar, Defense, supra note 1 , at 134 . 
former and the target of police investigation in the latter. ${ }^{57}$ Two cases, Katz v. United States ${ }^{58}$ and Miranda, exemplify the similarities and differences. In Katz, a case normally extolled for establishing the right to privacy, police officers sought to use an electronic listening device to obtain evidence that the defendant was engaged in illegal gambling activities. The Court acknowledged that the police officers correctly judged that there was sufficient probable cause to engage in the proposed surveillance, appropriately circumscribed the type of search conducted, and correctly predicted the occasions upon which Katz would converse about gambling. ${ }^{59}$

In Katz, then, the police did everything right except obtain a warrant prior to engaging in the search. The central problem, according to the Court, was "the inescapable fact ... that th[e] restraint was imposed by the agents themselves, not by a judicial officer." authorization of executive action -is the determinative issue in the Katz decision itself. Reasonableness depended upon ensuring that the agents' judgment was subjected to independent review. ${ }^{61}$

The importance of the warrant issue is obscured by the rights debate, which celebrates Katz as introducing an updated version of the right to privacy in criminal procedure. From a regulatory perspective, however, Katz should be remembered for re-emphasizing the regulatory use of warrants as a limitation on police activity. The clear, central purpose of Katz is to emphasize a particular style of regulation as constitutionally mandated. It perhaps seems fair to suggest that, rather than the Court's newly minted privacy doctrine ${ }^{62}$ misjudging the regulatory regime requiring judicial pre-authorization was the operative issue determining the outcome of Katz. ${ }^{63}$

57 Further complicating the picture are the different regimes applied by the Court to the nature of consent under the Fourth and Fifth Amendments, though these regimes differ more around the level of scrutiny, and so the issue of uniformity, rather than the source of scrutiny. Leaving the uniformity issues aside, for the moment, it is worth illustrating the role of the sources in scrutinizing police conduct before next asking what difference the source makes.

\footnotetext{
58389 U.S. 347 (1967).

59 Id. at 354 .

60 Id. at 356.
}

61 The same approach applies for the Fifth Amendment with Miranda wamings, and also, under executive-ascendant checks-and-balances regimes, where the judge is required to engage in a variety of colloquies to ensure the defendant is competent, and his decision is intelligent, knowing, and voluntary.

\section{Katz, 389 U.S. at 354-55.}

63 In Katz the government argued, and the Court acknowledged that even though (by applying the wrong privacy test) the agents misjudged whether the wire tap constituted a search, nonetheless, they "did no more here than they might properly have done with prior judicial sanction." Id. at 356. Accordingly, had a warrant been issued prior to the agents' interception of Katz's comments, those comments would still have been admissible under the new standard announced by the Court. Nonetheless, the Court held that there had been a constitutional violation, despite the agents' adventitious privacy-anticipating success, based upon their regulatory failure. In emphasizing the 
The Miranda case is most famous for the series of warnings it mandates prior to custodial questioning. ${ }^{64}$ As the Court acknowledges, the secrecy of custodial interrogations presented a central problem for judicial regulation. ${ }^{65}$ After all, most interrogations occurred in the stationhouse, away from third parties, and in particular, judicial review of the interrogation process. Secrecy enabled the police to shield their conduct from any meaningful scrutiny by the courts. ${ }^{66}$ The Court's regulatory regime in Miranda thus relied on obtaining consent from an informed suspect who was read a set of protocols to enforce clear norms of police conduct.

Whereas under the warrant regime the police obtain pre-authorization from a neutral third-party (the magistrate), under the warning regime in Miranda the police must obtain pre-authorization from an interested opponent. It is the suspect, fully informed of her rights and the consequences of confessing, who makes the decision to talk or to call for an attorney. Miranda accomplishes this shift in power by, first, mandating that the cops provide preset, mechanical warnings to ensure consent, and second, instituting a stringent waiver standard that puts the burden for establishing voluntariness firmly on the government. ${ }^{67}$ The warning regime thus attempts to transform the police role from autonomous-but-opaque to constrained-and-transparent, while preserving the use of confessions as a technique of police procedure.

Though lauded as rights decisions, both Katz and Miranda are better viewed from a regulatory perspective as providing two distinct styles of scrutiny. Each style depends upon adapting the regulatory regime to the person doing the regulating: the magistrate (in the case of warrants) or the target (in the case of interrogation). Perhaps the most obvious differences between these sources are, on the one hand, the presence or absence of legal expertise and, on the other hand, the presence or absence of some form of suspicion (even if inarticulate) that has drawn police attention. The person interrogated is usually a suspect in a criminal investigation who lacks legal expertise. Obtaining her consent serves to place officer and suspect in a functionally equal or non-hierarchical relationship, through the target's power to say "no" to the interrogation. Obtaining the independent

issues of source and stage, the Court noted "the usual requirement of advance authorization by a magistrate upon a showing of probable cause." Id. at 358. The Court emphasized "the safeguards provided by an objective predetermination of probable cause," $i d$., and rejected the government's proposed "substitut[ion of] . . . the far less reliable procedure of an after-the-event justification for the ... search, too likely to be subtly influenced by the familiar shortcomings of hindsight judgment." Id. (internal quotation marks and citation omitted).

64 The case itself stems from the arrest in Phoenix, Arizona, of Ernesto Miranda and his subsequent interrogation. Miranda v. Arizona, 384 U.S. 436, 491 (1966).

65 See id. at 445, 448.

66 Id. at 448 .

67 Only "[a]n express statement that the individual is willing to make a statement and does not want an attorney followed closely by a statement could constitute a waiver." Id. at 475 . Valid waivers would not be presumed. "[A]ny evidence that the accused was threatened, tricked, or cajoled into a waiver will, of course" vitiate the voluntariness of any waiver. Id. at 476. 
consent of a magistrate to engage in investigatory activity operates as a public, neutral limit upon law-enforcement's investigatory zeal. ${ }^{68}$ The touchstone of judicial regulation is the magistrate's ability, as legal expert, to force the police to defer to judicial interpretations of constitutional norms. ${ }^{69}$

\section{iii. Stage}

The primary difference between warrants and consent is that while both operate as a form of pre-screening, the latter also operates as a form of continuous monitoring during the search or interrogation process. ${ }^{70}$ Consent thus offers an opportunity unavailable in the warrant context: continuous monitoring of police conduct by the target of the investigation. ${ }^{71}$ Consent permits the target to exercise, not only individual pre-authorization at the start of the interview, but also continuous monitoring thereafter. ${ }^{72}$

68 See, e.g., Johnson v. United States, 333 U.S. 10, 13-14 (1948) (neutral magistrate essential to referee competitive enterprise of investigation); Aguilar v. Texas, 378 U.S. 108, 111 (1964) (neutral magistrate essential to determine probable cause exists); Shadwick v. City of Tampa, 407 U.S. 345, 348 (1972) (someone independent of police and prosecution must determine probable cause for issuance of warrant); Coolidge v. New Hampshire, 403 U.S. 443, 450 (1971) (executive official involved in prosecution of case not neutral and detached magistrate); United States v. United States D. for the E.D. of Mich., S. Div., 407 U.S. 297, 316-17 (1972) (executive branch official cannot be neutral magistrate for purposes of issuing warrants).

69 Of course, this view of the magistrate is particularly associated with the Warren Court. It subsequently received a number of severe blows, resulting in a non-expert and even (non-obviously) negligent magistrate being able to issue a warrant sufficient to justify police intrusion. See, e.g., Johnson, 333 U.S. at 13-14 (neutral magistrate essential to referee competitive enterprise of investigation); Shadwick, 407 U.S. 345 (court clerks who have neither judicial power nor legal training or experience can be authorized to issue warrants); Illinois v. Gates, 462 U.S. $213,235-36$ (1983) (court must pay great deference to the issuing magistrate's decision, even if the warrant was issued by the sort of untrained court functionary qualified to issue warrants under Shadwick).

70 In the Fourth Amendment context, the scope of consent limits the scope of the search. See Florida v. Jimeno, 500 U.S. 248, 251 (1991) (employing reasonableness standard to measure scope of target's consent). Under Miranda, a suspect can terminate consent at any time by invoking their rights to silence or to a lawyer. See Miranda v. Arizona, 384 U.S. 436, 444-45 (1966) (scope of interrogation determined by defendant's voluntary waiver of rights).

71 The efficacy of such regimes may be illusory. See, e.g., Janice Nadler, No Need to Shout: Bus Sweeps and the Psychology of Coercion, 2002 SUP. CT. REV. 153, $204-06$ (citing evidence from an Ohio study finding no decrease in consent rates after police were required to inform motorists of their right to refuse consent to searches). Nonetheless, the solution is not less consent, but a more effective system of warnings or raising the burden of proving consent. See Miranda, 384 U.S. at 475-76 (placing the burden of proving waiver on the government); Schneckloth v. Bustamonte, 412 U.S. 218, 285-86 (1973) (Marshall, J., dissenting) (requiring the government to prove knowledge of the right to refuse consent, implicitly a more robust consent standard).

72 Of course, both regimes are also enforced by retrospective review by the courts. That is, the judiciary may subsequently review the legality of the warrant and the nature of the search or seizure pursuant to its terms, as well as a consent search or interrogation. 


\section{iv. Uniformity}

Although both regimes mandate some form of independent review as a means of authorizing police conduct, and so are to that extent categorical, nonetheless, the style of review demanded of the magistrate or target is primarily individualized. On each occasion, the police apply for a warrant or seek consent, the magistrate or target makes a decision about whether to authorize police activity. This contrasts with categorical schemes that only require review when the parties bring alleged violations to an official's attention.

\section{B. Not Just Liberalism}

Although, as Sklansky indicates, ${ }^{73}$ the initial spur to judicial regulation of the police may have been lawless cops. That cannot be the whole story. The Court extolled the judgment of federal agents in both Katz and Miranda, and in the former case excluded evidence despite the agents' spot-on judgment calls as to the criminal activity and probable cause for a search. ${ }^{74}$ In Miranda, as Yale Kamisar notes, the Court justified the new set of warnings as compatible with the FBI's "exemplary record of effective law enforcement" while advising any suspect or arrested person of his rights at the outset of an interview. ${ }^{75}$ Certainly, the Miranda Court placed competitive worries of police over-exuberance firmly in the foreground of its analysis. ${ }^{76}$ Some form of independent oversight is necessary, the Court suggested, because self-regulation presents the possibility of a slide into unconstitutional coercion. ${ }^{77}$ Nonetheless, in Miranda as in Katz, the Court sought to demonstrate that the proposed regime of independent authorization is required to

73 See Sklansky, supra note 7, at 1731-41 (discussing the Warren Court as embracing judicial control of alienated police by binding them to rule of law).

74 Justice Stewart's majority opinion endorses "the Government's position . . . that its agents acted in [a] . . . defensible manner." Katz v. United States, 389 U.S. 347, 354 (1967). The opinion does not however, agree with the government that the agents' conduct was "entirely" defensible. Id.

75 Yale Kamisar, On the Fortieth Anniversary of the Miranda Case: Why We Needed It, How We Got It-And What Happened To It, 5 OHIO ST. J. CRIM. L. 163, 174 (2007).

76 "Even without employing brutality, the 'third degree' or the specific stratagems described above, the very fact of custodial interrogation exacts a heavy toll on individual liberty and trades on the weakness of individuals." Miranda, 384 U.S. at 455 . The Court later adds that even though the statements may not have been considered "involuntary in traditional terms ... [the] concern for adequate safeguards . . . is, of course, not lessened in the slightest." Id. at 457.

77 "Those who framed our Constitution and the Bill of Rights were ever aware of subtle encroachments on individual liberty. They knew that 'illegitimate and unconstitutional practices get their first footing . . . by silent approaches and slight deviations from legal modes of procedure." Id. at 459 (quoting Boyd v. United States, 116 U.S. 616, 635 (1886)). "It was necessary in Escobedo, as here, to insure that what was proclaimed in the Constitution had not become but a 'form of words' in the hands of government officials. And it is in this spirit, consistent with our role as judges, that we adhere to the principles of Escobedo today." Id. at 444 (citations omitted). 
constitute democratically accountable policing as much as to control lawless policing.

In other words, in each case the problem is not whether the cops were sufficiently well organized, but whether they are sufficiently accountable. It is immaterial to this mode of regulation whether the police are lawless, and therefore without any norms of law-abiding conduct, ${ }^{78}$ or opposed to the Court's norms (simply because they constrain police action or for other reasons, including political reasons), or whether they are efficiently and professionally organized and so potentially sympathetic to the model for Court reforms. ${ }^{79}$ What matters is that the Court establish a separate source of accountability for policing, and that this source operates as a type of independent review to ensure that policing comports with constitutional or judicial norms regardless of the attitudes of police departments or individual officers.

Accordingly, Sklansky's claim that the Court cares about accountability primarily in relation to the "competitive enterprise of ferreting out crime" first articulated in United States v. Johnson, ${ }^{80}$ is mistaken. Certainly, a central concern of both the Warren Court and its defenders is the problem of police discretion, and the worry that it permits lawless and even racist conduct. ${ }^{81}$ But the Court's worry cannot be just that the police are incapable of making the appropriate judgmentafter all, the agents in Katz got the privacy issue right one-hundred percent of the time. The point of independent review is that we want some extra guarantee of democratic accountability unavailable in systems based on self-regulation.

78 Here, the issue is not that the police are totally without norms, but that their norms are lawbreaking ones.

79 This is, I take it, the reason for citing the FBI practice in Miranda. See Kamisar, supra note 75, at 175-76 (discussing Chief Justice Warren's discussion of the FBI in conference and in the opinion).

80 Johnson v. United States, 333 U.S. 10, 14 (1948). Sklansky cites Johnson, Sklansky, supra note 7 , at 1734 , to suggest that the Warren Court manifests a "lurking wariness about the group psychology of the police." See id. at 1733.

81 Discretion permits arbitrary enforcement. That has been a particular worry given America's experience with racial discrimination. Accordingly, rights-oriented liberals often see independent, individualized pre-clearance of police action, often by judicial officers, as a remedy for the sort of oppressive or biased policing that results when cops are left to interpret and enforce the law according to their own personal values or preferences. See, e.g., Tracey Maclin, The Central Meaning of the Fourth Amendment, 35 WM. \& MARY L. REV. 197, 229 (1993) ("[T]he broad principle embodied in the Reasonableness Clause is that discretionary police power implicating Fourth Amendment interests cannot be trusted. The modern Court, nonetheless, insists that a rational basis model fulfills the central purpose of the Fourth Amendment. The law controlling the search of private containers exemplifies how the Court's current model promotes police power at the expense of Fourth Amendment freedoms."); Stephen J. Schulhofer, The Constitution and the Police: Individual Rights And Law Enforcement, 66 WASH. U. L.Q. 11, 18-19 (1988) (discussing lawenforcement bias of balancing model); Charles D. Weisselberg, Saving Miranda, 84 CORNELL L. REV. 109, 121 (1998) ("Miranda expressly represents a preference for Fifth Amendment values over the interests of law enforcement officers in obtaining incriminating statements."). 


\section{POLICE-ORIENTED REGULATION}

The last section considered two styles of independent review. Independent review is costly: warrants take time to obtain, and are not available in all circumstances. Warnings decrease the likelihood of consent and so require greater training and skill to elicit confessions. Where the police can game the system, either by their status as repeat players or their greater familiarity with the law, they increase cooperation at the expense of democratic accountability. I have suggested that these all raise criminological "questions of institutional structure: both the internal decisionmaking structures of police departments and the external processes of political control.",82

In this section, I shall consider two styles of regulation that look outside judicial regulation of police activity to managerial and training-based theories of police regulation. The first bucks the historical and intellectual trends, identified by Sklansky, towards a criminology and criminal procedure informed by participatory democracy, ${ }^{83}$ and instead harkens back to an earlier age of "'good government' managerialism." ${ }^{, 84}$ Rather than excluding discretion, as independent review tries to do, managerialism's goal was to control discretion by putting it in its place, using a top-down style of command-and-control to regulate what it believed was (or ought to be) an institutionally integrated, professional police force. That the managerial style of regulation ultimately failed to win the Court over to its precise prescription for regulation does not mean that the style is not influential: the Court embraced it (and continues to do so) in a modified form.

More profoundly perhaps, the Court also adopted a second, bottom-up style of self-regulation, one that is suspicious of the ability of general rules to guide police conduct, and which regards the police as relying on street-based training and experience to develop local norms of conduct. This style of regulation reflects the craft model of policing, one that suggests that law enforcement policy is formulated on the street and is not reducible to policies or principles. ${ }^{85}$ I shall argue in the next section that the Court justifies its more recent innovations in criminal procedure on the assumption that police training is sufficient protection against police violations of the Fourth and Fifth Amendment. The Court, it turns out, knows little or nothing about police training.

82 Sklansky, supra note 7, at 1799.

83 Id. at 1756-67 (discussing features of participatory democracy).

84 Id. at 1730 (quoting HeRMAN Goldstein, POlicing A Free SocIETY at 2-3, 133-34, 144 (1977).

85 David H. Bayley \& Egon Bittner, Learning the Skills of Policing, 47 LAW \& CONTEMP. ProBs. 35, 51 (1984) (craft of policing not reducible to principles). 


\section{A. Managerialism}

In line with the "second wave" movement towards police professionalism described by Sklansky, ${ }^{86}$ the managerialists view the police as a hierarchically organized executive institution, and so insist on treating law enforcement like any other agency by encouraging self-regulation through rule-making. ${ }^{87}$ Managerialism emphasizes that the goal of regulation should not be to eliminate police discretion, but to avoid its arbitrary exercise. The solution is to require lawenforcement officials to differentiate between discretionary and non-discretionary activities, and have the police or prosecutor draft clear guidelines or policies for each. ${ }^{88}$

The managerialist's point is to treat law enforcement like any other executive agency, obliging it to engage in the sort of policy-making that is the stuff of administrative operation and accountability. In this way, they hope to encourage the police to develop expansive and exhaustive policies to cover official conduct, even though such activity may be unrelated to the process of evidence-gathering that is the direct concern of independent review pre-clearance regimes. This goal is stated with characteristic directness by Anthony Amsterdam: "[u]nless a search or seizure is conducted pursuant to and in conformity with either legislation or police departmental rules and regulations, it is an unreasonable search and seizure prohibited by the fourth amendment. ${ }^{\prime 99}$ Accordingly, the absence of directives would be, of itself, a constitutional violation under Amsterdam's managerial style of regulation. Managerialism thus envisages self-regulation as a means of expanding the regulation of police conduct: directly, by the policy-making officials in the police department, and indirectly by judicial scrutiny of those policies. ${ }^{90}$

Police policy-making not only encourages law enforcement officials to buy into the process of regulation, ${ }^{91}$ but promulgating rules also has the advantage of

${ }^{86}$ Sklansky suggests that this "second wave [of police reformers] took 'professionalism' as their watchword." Sklansky, supra note 7, at 1743. Sklansky suggests that this mode of police reform proceeded upon a particular understanding of the organization of the police. "[T]hey tended to see police departments as first and foremost organizations not all that different from military or industrial units. ... [T] heir primary concerns were administrators' concerns: streamlining operations, strengthening lines of command, raising the quality of personnel, leveraging personnel with technology, clarifying the organizational mission, and building public support." Id. at 1742-43.

87 See LaFave, Controlling Discretion, supra note 19, at 445-51 (discussing history of arguments for police rulemaking).

88 See, e.g., Anthony G. Amsterdam, Perspectives on the Fourth Amendment, 58 Minn. L. Rev. 349, 416 (1974) (proposing that the Fourth Amendment should be interpreted to require police policy making); WAYNE R. LAFAVE, ARREST: THE DeCISION TO TAKE A SUSPECT INTO CuSTOdY 513 (1965) (Police ought to "reduce their enforcement policies to writing and subject them to a continuing process of critical re-evaluation.").

89 Amsterdam, supra note 88, at 416.

90 See, e.g., id.; LAFAVE, supra note 88 , at 513 .

91 See Amsterdam, supra note 88, at 416-25. 
promoting transparent interactions between police and public." "Police rulemaking would bring ... . [such norms] to visibility not merely for the police command but also for the community. Departmental rules would be subject to a kind of scrutiny by the community and by local political organs." 93

Managerialists thus envisage the police-and in particular, police policymakers - as the source of regulation. Senior officers are charged with developing uniform norms of police practice and transmitting those norms to subordinates prior to conduct. The Chief's power to set these bright-line rules is limited by her proper functions as a policy maker, and so is circumscribed by constitutional norms. ${ }^{94}$ The beat officer's power to enforce those rules is constrained to action in conformity with the rules. Where the Constitution generates such rules, the officials should interpret them in a manner that promotes clarity and affords the officer on the beat only ministerial authority. ${ }^{95}$ Police policy and constitutional norms thus prospectively establish what constitutes permissible police behavior: scrutiny then occurs retrospectively, to determine whether the officer did in fact comply with the categorical pre-published norms of conduct.

Perhaps the central case establishing this form of regulation in constitutional criminal procedure is New York v. Belton, ${ }^{96}$ where the Court established a brightline rule permitting a police officer to search the passenger compartment of a car upon the arrest of the driver. Justice Stewart, writing for the majority, emphasized the guiding function of judicial scrutiny: "When a person cannot know how a court will apply a settled principle to a recurring factual situation, that person cannot

92 See Carl McGowan, Rule-Making and the Police, 70 Mich. L. REV. 659, 667, 681 (1972) (stating that "it is the visibility of the administrative rulemaking process which is its greatest virtue.").

93 Amsterdam, supra note 88 , at $\mathbf{4 2 2}$.

The individual police officer ... . would be inclined to view his responsibilities more gravely and in broader perspective and to evaluate more thoroughly and thoughtfully the impact and propriety of various courses of action open to him. He would be both more accessible and more receptive to community input ... and he would stand to be judged and questioned by the department and the community upon irrefutable evidence of the content of the decision he had made.

Id. at 424 .

94 This type of policy-driven responsibility is also the model in civil suits, where issues of standing or qualified immunity premise liability upon the policy-making acts of officials, rather than isolated acts of wrongdoing. See, e.g., Monell v. Dep't of Soc. Serv. of N.Y., 436 U.S. 658 (1978) (to prevail in a 42 U.S.C. $\$ 1983$ lawsuit, plaintiff must show that the conduct of the municipality or its employee flowed from a "policy or custom"); Rizzo v. Goode, 423 U.S. 362, 375-82 (1976) (in the absence of the "existence of any overall Police Department policy to violate the legal and constitutional rights of citizens," plaintiffs lacked the requisite personal stake in overhauling police disciplinary procedures because alleged problems involved misconduct by a small number of policemen, were typical of those afflicting police departments in major urban areas, and none of the officers was alleged to have acted affirmatively in deprivation of constitutional rights of the plaintiff classes).

95 See, e.g., New York v. Belton, 453 U.S. 454, 458 (1981); Pennsylvania v. Mimms, 434 U.S. 106, 110-11 (1977).

96 Belton, 453 U.S. at 460-61. 
know the scope of his constitutional protection, nor can a policeman know the scope of his authority." 97 The Court's purpose is to show the police how to do things through clear, bright-line rules.

Managerialism emphasizes the importance of such guidelines for police conduct. According to Wayne LaFave:

[C]ertain search and seizure rules are expressed in terms of "standardized procedures" or a "set routine," that is, if . . some rules . . . "will be applied to all cases of [a certain] type, regardless of particular factual variations," in lieu of more sophisticated but less precise rules requiring ad hoc decision making by both police and courts. Such an approach seems particularly appropriate for those forms of police action which involve relatively minor intrusions into privacy, occur with great frequency, and virtually defy on-the-spot rationalization on the basis of the unique facts of the individual case. ${ }^{98}$

Some features of LaFave's managerial approach are worth recovering. The first is that his test seeks to announce a bright-line rule where police discretion can be reduced to some standard procedure. ${ }^{99}$ The second is that LaFave proposes a balancing test to determine which bright-line rules are permissible. The method is thus dialogic and solicitous of both police and citizen interests, rather than seeking to foist judicial regulation upon the police. The inquiry seeks to determine how much discretion the officer has, and should have, given the circumstances. Where the situation is run-of-the-mill, some sort of rule is both justified and required. The third is that the Court agreed with LaFave, quoting him directly and at length in Belton. ${ }^{100}$

Managerialism thus appears obsessed with the worry about institutional structure that Sklansky prescribes as a remedy for both criminal procedure and criminological scholarship. ${ }^{101}$ But Weisberg is correct to note that neither the academy nor the judiciary seizes the interdisciplinary moment. Police institutional structure is assumed to take a certain form rather than shown to do so. The turn away from a criminology of institutional structure is perhaps explained by a turn

97 Id. at $459-60$.

98 LaFave, The Robinson Dilemma, supra note 19, at 142-43 (citations omitted).

99 One might suggest that LaFave is concerned to announce "conduct" rather than "decision" rules to control police behavior.

100 Belton, 453 U.S. at 458 (quoting LaFave, The Robinson Dilemma, supra note 19, at 142). LaFave strongly disagreed with the result in Belton precisely because it got the balance wrong. Wayne R. LaFave, The Fourth Amendment in an Imperfect World: On Drawing "Bright Lines" and "Good Faith," 43 U. PITT. L. REV. 307, 325-33 (1982) [hereinafter LaFave, Imperfect World]; Wayne R. LaFave, Constitutional Rules for Police: A Matter of Style, 41 SYRACUSE L. REV. 849, 855 (1990) [hereinafter LaFave, Constitutional Rules].

101 See Sklansky, supra note 7, at 1799 (discussing institutional structure). 
towards a jurisprudence of rules and standards. ${ }^{102}$ For example, LaFave strongly disagreed with the result in Belton arguing that the Court created a rule where a standard was more appropriate. ${ }^{103}$ One of LaFave's central contentions is that the "bright-line" adopted in Belton, lacked the sort of clear boundaries necessary to render "case-by-case evaluation unnecessary." 104 His central regulatory argument is that constitutional norms "can only be realized if the police are acting under a set of rules which, in most instances, makes it possible to reach a correct determination beforehand as to whether an invasion of privacy is justified in the interest of law enforcement." 105 The problem in Belton is that the Court fails to produce such a rule.

\section{B. Craftsmen}

The issue in Belton is not just the Court's inability to formulate a rule that would be easy to administer in a more or less mechanistic manner. It is also the regulatory assumption that such a rule is necessary given the institutional structure of the police and the nature of crime on the street. Belton thus exposes a problem with governance by means of top-down policy-making. Some situations are not susceptible to regulation by rule: they are too unpredictable. In such circumstances, we need an institutional structure that rewards initiative and demands particular, specialized expertise. Rather than requiring unthinking ministerial applications of policy directives, this vision of crime and policing encourages street cops to develop policy on the fly and from the ground up. What is required is not a management cop, but a street cop: a craftsman, not a bureaucrat. $^{106}$ Such officers do not grow on trees. Skilled, responsive policing takes training and experience.

102 See, e.g., Duncan Kennedy, Form and Substance in Private Law Adjudication, 89 HARV. L. Rev. 1685, 1687-90 (1976) (discussing the conflict between rules and standards as representing different political perspectives); Kathleen M. Sullivan, Foreword: The Justices of Rules and Standards, 106 HARV. L. REV. 22, 69-92 (1992) (discussing three vectors along which the rules versus standards debate can play out: stare decisis, interpretation, and operative implementation).

103 See LaFave, Imperfect World, supra note 100, at 325-33; LaFave, Constitutional Rules, supra note 100 , at $855-56$.

104 LaFave, Constitutional Rules, supra note 100, at 855. See also LaFave, Imperfect World, supra note 100 , at $326-27$.

105 LaFave, The Robinson Dilemma, supra note 19, at 142.

106 On the difference between street and management cops, see, for example, Elizabeth ReussIanni \& Francis A. J. Ianni, Street Cops and Management Cops: The Two Cultures of Policing, in Control IN THE Police Organization 251 (Maurice Punch ed., 1983). On policing as a craft, see, for example, Egon Bittner, Legality and Workmanship: Introduction to Control in the Police Organization, in CONTROL IN THE POLICE ORGanization 1; Bayley \& Bittner, supra note 85, at 51 (portraying policing as a craft rather than a science). 
For craftsmen, ${ }^{107}$ policy is set by the officer on the street and is not reducible to policies or principles. ${ }^{108}$ Policing depends upon "craft" competence, characterized as "[e]xperience-tested good sense."109 Policy is viewed as local and partial. ${ }^{110}$ If experience is the only guide for policing, "the only people fit to judge police activity in encounters with the public are other experienced officers. Certainly civilians could not make fair judgments, but neither could supervisors who had not experienced the peculiarities of a specific situation." 111 Accordingly, neither the courts nor even the managerial cops prized by the administrative model are well placed to set policy for policing on the street. Accordingly, both should defer to well-trained and experienced cops as the real experts.

At the craft level, law-enforcement policy-making is characterized as disjointed and horizontal: the discretion to make tactical policy decisions exists at any level of the criminal justice process. ${ }^{12}$ Police officers are valued as pragmatic, skilled specialists responding to circumstances or difficulties faced on the job that are incapable of reduction to generalities through rules. ${ }^{113}$ Competence becomes the standard by which to assess administrative capability. ${ }^{114}$ What matters is the officials' ability to evaluate the intangible indicia of criminality effectively and accurately, or to make tactical decisions based upon bringing pragmatic skill or expertise to bear. ${ }^{115}$ The circumstances in which decisions must be made are incapable of reduction to formulas, and though rules cannot capture this fact, the appropriate training, imparting skill and experience in exercising judgment, can. ${ }^{116}$

${ }^{107}$ Egon Bittner, supra note 106; Bayley \& Bittner, supra note 85, at 51 (portraying policing as a craft rather than a science).

108 Bayley \& Bittner, supra note 85, at 51 (craft of policing not reducible to principles).

${ }^{109}$ Id. (internal quotation omitted).

${ }^{110}$ Whren v. United States, 517 U.S. 806, 815 (1996) (police policies too localized for purpose of Fourth Amendment).

111 Bayley \& Bittner, supra note 85, at 35.

112 See, e.g., Whren, 517 U.S. at 813.

113 See, e.g., Richards v. Wisconsin, 520 U.S. 385, 396 (1997) (in knock-and-announce case, "the Magistrate could not have anticipated in every particular the circumstances that would confront the officers when .... [T] hese actual circumstances ... justified the officers' ultimate decision to enter without first announcing their presence and authority."); United States v. Banks, 540 U.S. 31, 37, 41-42 (2003) (in knock-and-announce case, focus is on "the significance of exigency revealed by circumstances known to the officers "; use of technical "set of sub-rules" to "overl[ie] a categorical scheme on the general reasonableness analysis threatens to distort the 'totality of the circumstances' principle, by replacing a stress on revealing facts with resort to pigeonholes.").

114 See, e.g., United States v. Leon, 468 U.S. 897, 919 n.20 (1984); Hudson v. Michigan, 547 U.S. 586,599 (2006).

115 See Illinois v. Gates, 462 U.S. 213, 231 (1983). See also id. at 241; Ohio v. Robinette, 519 U.S. 33, 39-40 (1996); Florida v. Bostick, 501 U.S. 429 (1991); Florida v. Royer, 460 U.S. 491 (1983).

${ }^{116}$ See, e.g., Leon, 468 U.S. at 919 n.20; Hudson, 547 U.S. at 599. 
Given this rule-resistant horizontal model of administration, the Court prizes street-savvy excellence generated through training, experience, and practical skill. ${ }^{117}$ The craftsman style of regulation relies upon "practical" or commonsense standards, ${ }^{118}$ rather than determinate "technical" "tests" for the various standards of reasonableness. ${ }^{119}$ The touchstones of the case-by-case model are considerations of context ${ }^{120}$ and competence: promoting "independent police work"121 generates "endless variations in the facts and circumstances" that must be translated through experience or training into the decision to search, seize, or interrogate. ${ }^{122}$

Given the nature of the Fourth and Fifth Amendments, the Court's primary focus is on police competence in the practice of criminal investigation. ${ }^{123}$ In the investigatory sphere, an officer's professional competence extends beyond that which can be captured under a regime of institutional rules. Officers are not constrained by official rules or regulations promulgated by other officials. Rather, police officers are permitted to do what is reasonable. And what is reasonable is assessed based on the officer's training, skill, and experience, in light of the circumstances on the ground. ${ }^{124}$ This conception of reasonableness recognizes and

117 See, e.g., Leon, 468 U.S. at 919 n.20; Hudson, 547 U.S. at 599.

118 Gates, 462 U.S. at 231. Compare id. at 241, with id. 290 (Brennan, J., dissenting) ("Words such as 'practical,' 'nontechnical,' and 'common sense,' as used in the Court's opinion, are but code words for an overly permissive attitude towards police practices in derogation of the rights secured by the Fourth Amendment."). The Court "eschew[s] bright-line rules ... [or] 'litmus-paper test[s]' or single 'sentence or ... paragraph . . . rule[s]' . . or per se rule[s]." Robinette, 519 U.S. at 39 (citing Bostick, 501 U.S. at 429; Michigan v. Chesternut, 486 U.S. 567 (1988); Royer, 460 U.S. at 491).

119 Gates, 462 U.S. at 231.

120 See Royer, 460 U.S. at 506-07. See also Robinette, 519 U.S. at 40; Gates, 462 U.S. at $230-32$.

121 Gates, 462 U.S. at 241.

${ }^{122}$ Royer, 460 U.S. at 506. See United States v. Arvizu, 534 U.S. 266, 273 (2002); Ornelas v. United States, 517 U.S. 690, 699 (1996); United States v. Mendenhall, 446 U.S. 544, 563-64 (1980); Robinette, 519 U.S. at 39 ("[W]e have consistently eschewed bright-line rules, instead emphasizing the fact-specific nature of the reasonableness inquiry."). See also Florida v. Rodriguez, 469 U.S. 1, 6 (1984); Royer, 460 U.S. at 524-25 (Rehnquist, J., dissenting).

${ }^{123}$ Egon Bittner, however, suggests that the police are primarily engaged in (and competent to engage in) order-maintenance. EgON BITTNER, THE FUNCTIONS OF THE POLICE IN MODERN SOCIETY: a Review of Background factors, Current Practices, and Possible Role Models 41-44 (1970). Bittner's view certainly fits with the majority of the training received by trainees in the police academies. See MiChael D. White, CuRRENT Issues and Controversies IN PolicIng 42 (2007) (in police training, "large blocks of time ... are devoted [to] danger-related skills.").

124 See, e.g., Hudson v. Michigan, 547 U.S. 586, 599 (2006) (discussing reforms in police training); Brigham City v. Stuart, 547 U.S. 398 (2006) (manner of entry into house objectively reasonable given circumstances of noisy party); Illinois v. Wardlow, 528 U.S. 119, 122, 124-25 (2000) (permitting search for weapons "because in [the officer's] experience it was common for there to be weapons in the near vicinity of narcotics transactions."); Arvizu, 534 U.S. at 273 ("[R]eviewing courts should ... look at the 'totality of the circumstances' of each case .... This process allows officers to draw on their own experience and specialized training to make inferences from and deductions about the cumulative information available to them that 'might well elude an untrained person."); Ornelas, 517 U.S. at 699 (suggesting that "a police officer views the facts through the lens 
supports the need for spontaneous applications of professional judgment, particularly in difficult and rapidly evolving or highly nuanced situations.

Policing-as-a-craft has both an upside and a downside. The upside is that good, experienced officers on the street can recognize and respond to crime in a variety of preventative ways to solve problems and engage the community. The downside is that it may be difficult to distinguish good police craft from simple shows of authority, ${ }^{125}$ and hard to transmit the techniques of "good" policing to junior officers. If craft is predominantly a matter of individual style, ${ }^{126}$ then we are in even worse shape, because there will be little uniformity even across experienced officers. Accordingly, the goal of regulation may be either to empower craft competence by removing technical rules or to constrain craft incompetence by requiring pre-clearance of action. Furthermore, some form of continued training, perhaps by requiring periodic certification of competence, may be appropriate to ensure that standards are maintained and that officers continue to develop good skills in line with the latest technical innovations.

Answering the questions of source, stage, and uniformity from the craftsman perspective tends to produce two different results. If we want to encourage police officers to act as craftsmen, then empowering the officer on the street as both policy-maker and judge of competence seems essential. Prospective norms guiding behavior are sub-optimal: what we want are experienced, street-savvy officers as the source of regulation operating after the police have had a chance to size-up and respond to the situation, using case-by-case evaluations of competence.

If we want to constrain the police and scrutinize their craftsman-like conduct, then we will want some independent source to ensure that policing comports with constitutional norms (and so independently authorize police activity), probably before the police have a chance to act, while engaging in an individualized analysis of proposed action to remain responsive to the situational nature of the craft. ${ }^{127}$

of his police experience and expertise" and discussing a range of otherwise innocuous facts that will justify suspicion by a well-trained officer); Rodriguez, 469 U.S. at 6 (discussing the contribution of police training to the establishment of articulable suspicion); Royer, 460 U.S. at 525 (Rehnquist, J., dissenting) ("Any one of these factors relied upon by the Miami police may have been as consistent with innocence as with guilt; but the combination of several of these factors is the essence of both 'articulable suspicion' and 'probable cause."); Mendenhall, 446 U.S. at 563 ("[I]t is important to recall that a trained law enforcement agent may be 'able to perceive and articulate meaning in given conduct which would be wholly innocent to the untrained observer."') (quoting Brown v. Texas, 443 U.S. 47, 52 n.2 (1979)); United States v. Cortez, 449 U.S. 411, 421-22 (1981) ("[T] he question is whether, based upon the whole picture, they, as experienced Border Patrol officers, could reasonably surmise that the particular vehicle they stopped was engaged in criminal activity.").

125 "Officers say experience teaches them what works. But does it? . . Perhaps almost anything 'works' most of the time, largely because the police are so authoritative in relation to the people with whom they have to deal." Bayley \& Bittner, supra note 85, at 47.

126 Peter K. Manning, Policing Contingencies 180 (2003) (the "craft [has] uncertain contours ... [and police] styles and tactics vary widely.").

${ }^{127}$ In Katz, the Court emphasized the importance of judicial pre-screening before police investigation, rather than after-the-fact review, insisting on the "safeguards provided by an objective predetermination of probable cause, and substitutes instead the far less reliable procedure of an after- 
The Court has recently emphasized the craftsman-style of policing by encouraging courts to rely upon police training and experience. ${ }^{128}$ In tandem with its emphasis on training and experience, the Court has tended to adopt a minimalist approach to agency regulation. The judiciary engages in an evaluation of the circumstances surrounding each decision to determine whether it evinced a tolerable appreciation of constitutional norms and, so long as the conduct passes constitutional muster, leaves further scrutiny to the police department's internal disciplinary process, a citizen review board, or some licensing agency. ${ }^{129}$

This form of criminal procedure, then, looks outside the system of court regulation to resolve most regulatory issues. The appropriate stance of criminal procedure, and one embraced by proponents of participatory democracy and community policing, is interdisciplinary, seeking alternative checks on the practice of policing.

\section{Craftsmanship in Contemporary Criminal Procedure}

Policing as a craft is particularly associated with the problem-solving and community-policing initiatives that have gained ground in recent years, both "on the ground" and as the cutting edge of the "new" scholarship on criminal procedure. But the craft model is generally contrasted with or opposed to the administrative or professionalism model of policing. For example, Debra Livingston has argued that community policing requires not balancing constitutional rights against policing interests, but replacing the vagueness doctrine's (over) sensitivity to constitutional norms with a heightened sensitivity to local, citizen driven norms or community values. ${ }^{130}$ Tracey Meares and Dan Kahan have made similar arguments in the context of anti-gang ordinances. ${ }^{131}$

The community norms model of policing expressly views the cop as craftsman, emphasizing the officer's local knowledge and responsiveness to

the-event justification for the . . . search, too likely to be subtly influenced by the familiar shortcomings of hindsight judgment." Katz v. United States, 389 U.S. 347, 358 (1967) (citation and internal quotation marks omitted).

128 See, e.g., Wardlow, 528 U.S. at 122 (emphasizing police officer's experience and commonsense judgments about human behavior); Arvizu, 534 U.S. at 273 (permitting "officers to draw on their own experience and specialized training"); Ornelas, 517 U.S. at 699 (suggesting that "a police officer views the facts through the lens of his police experience and expertise"); Rodriguez, 469 U.S. at 6 (discussing the contribution of police training to the establishment of articulable suspicion).

129 See, e.g., Hudson, 547 U.S. at 599; id. at 603 (Kennedy, J., concurring).

130 See Debra Livingston, Police Discretion and the Quality of Life in Public Places: Courts, Communities, and the New Policing, 97 CoLUM. L. REv. 551 (1997).

131 See Tracey L. Meares, Place and Crime, 73 CHI.-KenT L. REV. 669 (1998); Meares \& Kahan, supra note 14; Tracey L. Meares \& Dan M. Kahan, Foreword: The Coming Crisis of Criminal Procedure, 86 GEO. L.J. 1153 (1998). 
problems on the ground. ${ }^{132}$ One goal of community policing requires departments to become more decentralized and more horizontal, with the management class becoming more supportive and responsive to street officer's experiences of policing on the street, and empowering police-as-craftsmen to act upon their expertise. ${ }^{133}$ Reducing both judicial and departmental scrutiny of police conduct to facilitate craftsmanship, however, undermines scrutiny and control of street cops' conduct.

The craftsman understanding of policing fits more comfortably within Sklansky's account of the recent trends in criminal procedure as influenced by participatory democracy, one he suggests is closely associated with the embrace of community policing. ${ }^{134}$ Participatory democracy, particularly in its apologetic mode, manifests a "disenchantment with [the top-down, managerial model of] police professionalism"135 and so embraces a "strain of anti-elitism ... often tak[ing] the form, both in scholarship and in jurisprudence, of hostility to claims of professional expertise and pronounced distrust of . . . judges, administrators, and civil libertarians." ${ }^{136}$ It seeks to establish a form of conversation between different stakeholders about the process of policing. ${ }^{137}$

The craftsman approach prized by this bottom-up jurisprudence of policing recalibrates professionalism as the ability to evaluate the intangible indicia of criminality effectively and accurately, or to make tactical decisions based upon bringing pragmatic skill or expertise to bear. ${ }^{138}$ Accordingly, " $[t]$ he problem of police discretion ... exercises the current generation of criminal procedure scholars much less ... [ [resulting in] call[s] for a relaxation of 'discretion suspicion." "139 Discretion is necessary because the circumstances in which decisions must be made are incapable of reduction to formulas, and though rules

132 See Debra Livingston, Gang Loitering, the Court, and Some Realism About Police Patrol, 1999 SUP. CT. REV. 141, 173, 198-99; Meares, supra note 14, at 404; WhITE, supra note 123, at 98; George L. Kelling \& Catherine M. Coles, FiXIng Broken Windows: Restoring ORder and REDUCING CRIME IN OUR COMMUNITIES 21-25, 30-37, 242-43, 247-57 (1996).

133 See, e.g., SAmuel Walker \& Charles M. KaTZ, The Police IN America: AN INTRODUCTION (2008) (discussing restructuring necessary for community policing).

134 Sklansky, supra note 7 , at $1778-85$ (discussing recent trends in criminal procedure scholarship embracing community policing).

135 Id. at 1794.

136 Id. at 1790.

137 Id. (discussing importance of "conversation" to criminal procedure theorists interested in establishing transparent processes).

138 See Illinois v. Gates, 462 U.S. 213,231 (1983). See also id. at 241; Ohio v. Robinette, 519 U.S. 33, 39-40 (1996); Florida v. Bostick, 501 U.S. 429 (1991); Florida v. Royer, 460 U.S. 491 (1983).

139 Sklansky, supra note 7, at 1790-91. 
cannot capture this fact, the appropriate training, imparting skill and experience in exercising judgment, can. ${ }^{140}$

The Court has, on occasion, embraced this form of delegated discretion. In a number of cases, it has extolled police training, experience, and practical skill precisely because policy-based dissemination of constitutional norms is ruleresistant. ${ }^{141}$ The Court relies upon "practical" or commonsense standards, ${ }^{142}$ rather than determinate "technical" "tests" for the various standards of reasonableness. ${ }^{143}$ It promotes considerations of context ${ }^{144}$ and competence: "independent police work" "145 generates "endless variations in the facts and circumstances" that must be translated through experience or training into the decision to search, seize, or interrogate. ${ }^{146}$

The Court engages in a mode of scrutiny that rejects the application of both judicially and professionally generated rigid rules of conduct in favor of a case-bycase, totality-of-the-circumstances analysis. ${ }^{147}$ So long as the official is properly trained and manifests some appropriate response to the circumstances triggering constitutional scrutiny, the Court refuses to second-guess her assessment, particularly in difficult and rapidly evolving or highly nuanced situations. ${ }^{148}$ The touchstone of this style of regulation is professional competence. ${ }^{149}$ So long as the

140 See, e.g., United States v. Leon, 468 U.S. 897, 919 n.20 (1984); Hudson v. Michigan, 547 U.S. 586, 599 (2006).

141 See, e.g., Leon, 468 U.S. at 919 n.20; Hudson, 547 U.S. at 599.

142 Gates, 462 U.S. at 231. Compare id. at 241, with id. at 290 (Brennan, J., dissenting) ("words such as 'practical,' 'nontechnical,' and 'common sense,' as used in the Court's opinion, are but code words for an overly permissive attitude towards police practices in derogation of the rights secured by the Fourth Amendment."). The Court "eschew[s] bright-line rules ... [or] "litmus-paper test[s]' or single 'sentence or ... paragraph . . . rule[s]' . . or per se rule[s]." Robinette, 519 U.S. at 39 (citing Bostick, 501 U.S. 429; Michigan v. Chesternut, 486 U.S. 567 (1988); Royer, 460 U.S. 491 ).

143 Gates, 462 U.S. at 231.

144 See Royer, 460 U.S. at 506-07. See also Robinette, 519 U.S. at 40; Gates, 462 U.S. at 230 32.

145 Gates, 462 U.S. at 241.

146 See United States v. Arvizu, 534 U.S. 266, 273 (2003); Ornelas v. United States, 517 U.S. 690, 699 (1996); United States v. Mendenhall, 446 U.S. 544, 563-64 (1980); Robinette, 519 U.S. at 39 ("[W]e have consistently eschewed bright-line rules, instead emphasizing the fact-specific nature of the reasonableness inquiry"); see also Florida v. Rodriguez, 469 U.S. 1, 6 (1984); Royer, 460 U.S. at 524-25 (Rehnquist, J., dissenting).

147 See Gates, 462 U.S. 213 (replacing rigid rules of probable cause established by AguillarSpinelli with totality of the circumstances, case-by-case analysis of probable cause); Leon, 468 U.S. 897, 919-23 (1984) (employing totality of the circumstances, case-by-case analysis to assess reasonableness of police reliance on warrant).

148 See, e.g., Brigham City v. Stuart, 547 U.S. 398 (2006) (totality of circumstances analysis applied to difficult judgments in know-and-announce cases); United States v. Banks, 540 U.S. 31, 37 , 41 (2003); Richards v. Wisconsin, 520 U.S. 385, 396 (1997).

149 Hudson, 547 U.S. 586, 603 (2006) (Kennedy, J., concurring) (“Our system, as the Court explains, has developed procedures for training police officers and imposing discipline for failures to act competently and lawfully."); Wilson v. Layne, 526 U.S. 603, 618 (1999) (Stevens, J., concurring 
officer is sufficiently well trained and professional, the Court will defer to her onthe-spot tactical judgments rather than rely upon the sort of departmental procedures managerialists found essential under the Fourth Amendment. Two cases exemplify this approach.

In Whren v. United States, ${ }^{150}$ for example, the Court refused to exclude evidence simply because the police failed to follow departmental policy guidelines in conducting a traffic stop. ${ }^{151}$ The Court advanced two reasons for its reluctance: that it would require courts "to speculat[e] about the hypothetical reaction of a hypothetical constable - an exercise that might be called virtual subjectivity"; ${ }^{152}$ and that, unlike the Fourth Amendment, "police enforcement practices . . . vary from place to place and from time to time." 153 Such variability in the rules is a "trivialit[y]" that does not have a constitutional dimension. ${ }^{154}$

In Ornelas v. United States, ${ }^{155}$ the Court indicated that the "fact" of training is not merely one among others; rather, it is the lens through which the other circumstances are refracted when considering their significance. ${ }^{156}$ The Court held that appellate courts are to give as much deference to the "inferences drawn from th[e] facts" by law enforcement officers as by judges. ${ }^{157}$ The officers' ability to explain how otherwise-innocent conduct is, under the circumstances and properly understood, suspicious, ${ }^{158}$ characterizes the police as well-trained, street-level experts responding to evidence of criminality that outsiders may be unable to

in part and dissenting in part) ("My sincere respect for the competence of the typical member of the law enforcement profession precludes my assent to the suggestion that 'a reasonable officer could have believed that bringing members of the media into a home during the execution of an arrest warrant was lawful."”).

150517 U.S. 806 (1996).

151 Id. at 815 (citing Metropolitan Police Department, Washington, D.C., General Order 303.1, pt. 1, Objectives and Policies (A)(2)(4) (Apr. 30, 1992), reprinted as Addendum to Brief for Petitioners).

${ }^{152}$ Id. (noting that "police manuals and standard procedures may sometimes provide objective assistance").

${ }^{153}$ Id. (noting that "District of Columbia police regulations which permit plainclothes officers in unmarked vehicles to enforce traffic laws ... would not apply in jurisdictions that had a different practice. And . . . would not have applied even in the District of Columbia, [dependant upon differences between officers in plain clothes or driving unmarked cars, and officers] wearing a uniform or patrolling in a marked police cruiser.").

${ }^{154}$ Id.

155517 U.S. 690 (1996).

${ }^{156}$ Id. at 699. See also Arvizu, 534 U.S. 266, 273 (2002) (the totality-of-the-circumstances inquiry "allows officers to draw on their own experience and specialized training to make inferences from and deductions about the cumulative information available to them that 'might well elude an untrained person."”).

157 Ornelas, 517 U.S. at 699. As David Sklansky notes, "the Court in effect declared that police officers should receive as much deference as trial judges." David A. Sklansky, Traffic Stops, Minority Motorists, and the Future of the Fourth Amendment, 1997 SUP. CT. REV. 271, 301.

${ }^{158}$ See, e.g., United States v. Sokolow, 490 U.S. 1, 8-10 (1989). 
recognize. An officer's articulation of her experience displays her qualifications and establishes her street-savvy expertise. ${ }^{159}$ So long as the officer is properly trained and manifests some appropriate response to the circumstances triggering constitutional scrutiny, the Court refuses to second-guess her assessment.

Whren and Ornelas were decided within two weeks of each other; taken together they mark a strong preference for a craftsman model of police professionalism. Both emphasize the "unitary"160 and invariable ${ }^{161}$ sweep of the Fourth Amendment as part of the objective, reasonable officer, test for probable cause, and seek to protect it from the local or fragmented decisions of police departments (in Whren) ${ }^{162}$ and trial courts (in Ornelas). ${ }^{163}$ Yet in Ornelas the officer's training and experience substitutes for any fact-finding by the district court. ${ }^{164}$ The Court insisted that "a police officer may draw inferences based on his own experience in deciding whether probable cause exists." 165 Thus, although the Court will not inquire as to what motivated an officer's decision, it will consider, as part of the objective set of circumstances, the officer's description of what her skill and training led her to notice or conclude. The Court's objective test relies upon the subjective judgments of sufficiently skilled individual police officers. Accordingly, the uniform standard argument can only be supported by either some essentialist belief in police judgment or some unstated belief in the uniformity of police training standards. Certainly, the first assumption is unsupported and unsupportable.

What the Court ends up with as a result of its decisions in Ornelas and Whren is a personalized Fourth Amendment, in which what counts as probable cause or reasonable suspicion depends upon the particularized training and experience of individual police officers. This result is ironic, given its rejection in Whren of the

159 See Arvizu, 534 U.S. at 273 ("[R]eviewing courts should . . . look at the "totality of the circumstances' of each case .... This process allows officers to draw on their own experience and specialized training to make inferences from and deductions about the cumulative information available to them that "might well elude an untrained person." ); Ornelas, 517 U.S. at 699 (suggesting that "a police officer views the facts through the lens of his police experience and expertise" and discussing a range of otherwise innocuous facts that will justify suspicion by a well-trained officer); Florida v. Rodriguez, 469 U.S. 1, 6 (1984) (discussing the contribution of police training to the establishment of articulable suspicion); Florida v. Royer, 460 U.S. 491, 525 (1983) (Rehnquist, J., dissenting) ("Any one of these factors relied upon by the Miami police may have been as consistent with innocence as with guilt; but the combination of several of these factors is the essence of both 'articulable suspicion' and 'probable cause."'); United States v. Mendenhall, 446 U.S. 544, 563 (1980) ("[I]t is important to recall that a trained law-enforcement agent may be "able to perceive and articulate meaning in given conduct which would be wholly innocent to the untrained observer."') (quoting Brown v. Texas, 443 U.S. 47, 52 n.2 (1979)).
160 Ornelas, 517 U.S. at 697.
161 Whren, 517 U.S. at 815.
162 Id.
163 Ornelas, 517 U.S. at 697.
164 Id. at 699.
165 Id. at 700. 
managerial model's reliance on departmental policy as too localized and in Ornelas of judicial pre-screening insufficiently uniform. Yet without the assurance of national standards defining the content of police training programs, and in particular training in the probable cause and reasonable suspicion standards, what the Court risks is at best localized standards, and at worst individualized ones. What the Court refuses to provide is some evidence that police training produces a uniform lens through which to view evidence of criminal activity. ${ }^{166}$

\section{THE COURT AND THE INSTITUTIONAL STRUCTURE OF THE POLICE}

The Court's discussions of police officer training primarily crop up in two Fourth Amendment categories of cases. Most commonly, the Court emphasizes police officer training in the context of establishing probable cause or reasonable suspicion, ${ }^{167}$ and uses the latter standard to carve out exceptions to the warrant requirement. ${ }^{168}$ Less commonly, but just as importantly, the Court periodically suggests that training is an alternative to the exclusionary rule as a means of enforcing constitutional norms. The two cases in which the Court has advanced this position most strongly are United States v. Leon ${ }^{169}$ and Hudson v. Michigan. ${ }^{170}$

In Leon, the Court indicated its willingness to limit, and perhaps render insignificant, the exclusionary rule. It then waited almost two decades before signaling, in Hudson, that it may be willing to make good on its promise. Both cases, however, provide an example of the Court's openness to institutional structure as determinative of both the style of regulation and the available remedy. And both cases purport to rely upon the sort of social science literature identified by Weisberg and Sklansky. In fact, two champions of the application of social science data in criminal procedure, Tracey Meares and Bernard Harcourt, cite to Leon as exemplifying the manner in which social science research should be used by the judiciary in developing criminal procedure norms. ${ }^{171}$ In Leon, they point out:

166 Illinois v. Wardlow, 528 U.S. 1 19, 122, 124-25 (2000) (rejecting social science as the basis for establishing probable cause because "courts do not have available empirical studies dealing with inferences drawn from suspicious behavior, and we cannot reasonably demand scientific certainty from judges or law enforcement officers where none exists. Thus, the determination of reasonable suspicion must be based on commonsense judgments and inferences about human behavior.").

167 See United States v. Sokolow, 490 U.S. 1, 7 (1989) (citing Illinois v. Gates, 462 U.S. 213 , 232 (1983)). See also United States v. Arvizu, 534 U.S. 266, 274 (2003) (reasonable suspicion is "somewhat abstract"; "not a finely-tuned standar[d]"; "an elusive concept") (citations omitted).

${ }^{168}$ See, e.g., Terry v. Ohio, 392 U.S. 1 (1968).

169468 U.S. 897, 919-23 (1984).

170547 U.S. $586(2006)$

171 See, e.g., Meares \& Harcourt, supra note 13, at 746-49. Meares and Harcourt concentrate on a different set of studies in Leon than I do. See id. at 747 (discussing Justice White's reliance on "nascent research on the effect of the exclusionary rule on the disposition of felony arrests"). I am more interested in the social science data used to justify the remedy, not the right; and while in both Leon and Hudson the Court relies on some social science data, it generally misinterprets it. 
Both the majority and the dissenters are relying on the same study, but each side uses the study to promote a different viewpoint concerning the value of the exclusionary rule. . . In Leon, the interpretive choices are made clear-are transparent-because the justices set forth and discuss the empirical backdrop against which they are deciding. ${ }^{172}$

In this section, I shall argue that though the Court in both Leon and Hudson claimed to rely on social science research in its discussions of institutional structure, in each case the Court refused to engage in a rigorous analysis of the relevant data. Both cases nonetheless demonstrate that criminology, of the sort identified by Weisberg and Sklansky, can inform judicial decision-making and should inform academic study.

\section{A. United States v. Leon}

In Leon, the question of reasonableness arose when "an experienced and welltrained narcotics investigator" ${ }^{173}$ received a tip about a drug deal that had occurred five months earlier. After the officer prepared an application for a search warrant that was then reviewed by several Deputy District Attorneys and issued by a magistrate, ${ }^{174}$ he searched Leon's property and discovered illegal narcotics. The warrant was improperly issued, though validly executed. ${ }^{175}$ The Court held that the Fourth Amendment does not require a showing of subjective good-faith to avoid exclusion of evidence obtained pursuant to a defective warrant. ${ }^{176}$ Rather, in carrying out her official duties, a "reasonably well trained officer should rely on the warrant" unless it is apparent that "the issuing magistrate wholly abandoned his judicial role." 177

Leon introduced the "good faith" exception to the warrant requirement. ${ }^{178}$ In particular, the Court relied upon a deterrence rationale to avoid excluding the evidence. The Court held that the exclusionary remedy could be justified only if it would directly affect police conduct: "If exclusion of evidence obtained pursuant to a subsequently invalidated warrant is to have any deterrent effect . . . it must alter the behavior of individual law enforcement officers or the policies of their departments." 179 The Court then purported to rely upon social science data to determine the effect of exclusion.

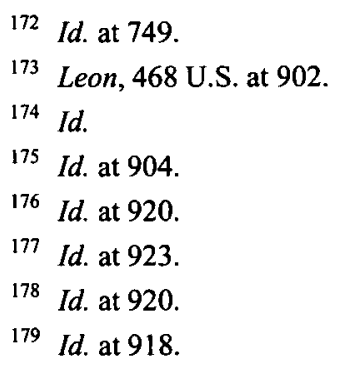


The Court considered at least two exclusionary effects. It cited a voluminous amount of social science data to evaluate the effect of exclusion on the success of criminal prosecutions. ${ }^{180}$ But the Court was less stringent in supporting its claim about the effect of exclusion upon the police, the intended targets of exclusion's deterrent effect. Instead, the Court relied primarily upon a citation to an article by Jerold Israel arguing that:

The key to the [exclusionary] rule's effectiveness as a deterrent lies, I believe, in the impetus it has provided to police training programs that make officers aware of the limits imposed by the fourth amendment and emphasize the need to operate within those limits. [An objective goodfaith exception] is not likely to result in the elimination of such programs, which are now viewed as an important aspect of police professionalism. ${ }^{181}$

Here the Court claims, along with Israel, that the exclusionary rule operates, not at the level of particular officers, but rather at the level of departmental policy setting. Its effectiveness is in persuading states or police departments, when designing training programs, to include instruction in the Fourth Amendment or risk the consequences. Unlike the social science data about criminal prosecutions, however, the Court provides no evidence that training programs work in this way. In fact, in a portion of his article not cited by the court, Israel admits: "I must confess that I have no empirical support for this prediction aside from conversations with persons engaged in police training programs and [by] the remote analogy presented by the treatment of [the dissemination of Supreme Court precedent in interrogation] training programs." ${ }^{182}$

Rather than simply hope that the exclusionary rule generally provides greater transparency in the training process, the Court could have examined real data about the content and efficiency of training programs, even to the limited extent that Chief Justice Warren did in Miranda, to determine whether the police were in fact trained in the operation of the Fourth Amendment. ${ }^{183}$ Instead, the Leon Court

180 Id. at 908 .

181 Id. at 919 (quoting Israel, supra note 19, at 1412-13 (footnotes omitted)). Israel's article continues: "Neither is it likely to alter the tenor of those programs; the possibility that illegally obtained evidence may be admitted in borderline cases is unlikely to encourage police instructors to pay less attention to fourth amendment limitations. Finally, [it] should not encourage officers to pay less attention to what they are taught, as the requirement that the officer act in 'good faith' is inconsistent with closing one's mind to the possibility of illegality." Israel, supra note 19, at 141213.

182 Israel, supra note 19 , at 1412 n.390.

183 See, e.g., M. L. Dantzker, Police Academies and Their Curriculum: Beginning the Exploration, PoLICE F., Apr. 2000, at 4, 4-7; Terry D. Edwards, State Police Basic Training Programs: An Assessment of Course Content and Instructional Methodology, 12 AM. J. POLICE 23, 23-45 (1993). See also Illinois v. Caballes, 543 U.S. 405, $411-13$ (2005) (Souter, J., dissenting) (discussing statistical evidence on accuracy of dogs trained in drug-sniffing). 
assumes, without much discussion, that the police training programs do in fact make the police officers aware of the contours of the Fourth Amendment. It makes a criminological assertion, one that is decisive for the case, without finding the data to back it up.

\section{B. Hudson v. Michigan}

Hudson v. Michigan ${ }^{184}$ is a knock-and-announce case, in which the police executed a valid warrant by "announc[ing] their presence, but waited only . . . 'three to five seconds' . . . before turning the knob of the unlocked front door and entering Hudson's home." 185 The State conceded that this form of entry was a violation of the "reasonable wait time" standard established in United States $v$. Banks. ${ }^{186}$ Accordingly, the only issue on appeal was whether the remedy of exclusion should apply.

In Hudson, the Court justified a potentially far-ranging limitation on the exclusionary rule based on "the increasing professionalism of police forces, including a new emphasis on internal police discipline." 187 Mimicking Chief Justice Warren's approach in Miranda (albeit somewhat half-heartedly), and adopting the method it should have applied in Leon, the Court cited a range of social science data and police practice handbooks. ${ }^{188}$ The Court extolled the existence of "[n]umerous sources ... available to teach officers and their supervisors ... how to respect constitutional guarantees in various situations, and how to craft an effective regime for internal discipline." 189 Central to the dissemination of this information are the "wide-ranging reforms in the education, training, and supervision of police officers," that are part of the professionalization process. ${ }^{190}$

As in Leon, the Court's conclusion was that these training materials evidenced police professionalism and demonstrated that law enforcement should be the primary source of police discipline. The modern police force places:

a new emphasis on internal police discipline. ... [W]e now have increasing evidence that police forces across the United States take the

184547 U.S. 586 (2006).

185 Id. at 588.

186540 U.S. 31,41 (2003). See Hudson, 547 U.S. at 590.

${ }^{187}$ Hudson, 547 U.S. at 598.

188 The Court cited to: SAMUEl Walker, TAMing the System: THE CONTROL of DisCretion in Criminal Justice 1950-1990, at 51 (1993), as well as David M. WAKSMan \& DebBie J. Goodman, The Search and SeIZURe HandBooK (2d ed. 2006); Alfred R. StONe \& Stuart M. Deluca, Police Administration: An InTRODUction (2d ed. 1994); Edward A. Thibault et al., Proactive Police Management (4th ed. 1998). See Hudson, 547 U.S. at 599.

189 Hudson, 547 U.S. at 599.

190 Id. (emphasis added) (quoting WALKER, supra note 188, at 51). 
constitutional rights of citizens seriously .... [M]odern police forces are staffed with professionals; it is not credible to assert that internal discipline, which can limit successful careers, will not have a deterrent effect. There is also evidence that the increasing use of various forms of citizen review can enhance police accountability. ${ }^{191}$

From a regulatory perspective, two features are worth noting. First, the deterrence rationale decouples the police chain of command from the courts. Courts no longer operate in a regulatory regime in which police are sandwiched between judicial pre-clearance and post-hoc review. The warrant operates in a formalistic way to insulate subsequent police action from judicial sanction. Second, the responsibility for regulation depends upon a separate scheme of police-sponsored pre-authorization and retrospective review. As in Leon, the Court relies upon, and expresses its confidence in, the transmission of Fourth Amendment norms through training manuals, ${ }^{192}$ and believes that internal discipline can effectively scrutinize and discipline the police for any lapses in professionalism. Training acts on the front end as a categorical pre-clearance device. Internal review acts at the back-end as a direct check on officer misconduct where (the Court feels confident, given its review of the empirical data) exclusion cannot. ${ }^{193}$

The Court thus stakes its regulatory regime upon a criminological claim about the institutional structure of the police, and police training. My goal is not primarily to defend the remedy of exclusion, but to show that training and experience are important concepts in the Court's Fourth Amendment jurisprudence. Nonetheless, it is worth noting two things about the Hudson decision. First, if the Court is wrong about training and wrong about citizen review or tort lawsuits, then exclusion may be back on the table as an admittedly distant, but not too remote way to control the police. It is not an ideal mode of regulation, but if it is the only effective mode of regulating the police, its increased importance would render even an attenuated deterrent effect worthwhile. Second, if the Court is wrong about the interaction of exclusion and police training-if, that is, the police are trained through the exclusion process - then exclusion becomes a much more direct and proximate remedy, one that is vital to the regulatory regime of training and discipline envisaged by the Court. Both these issues are susceptible to demonstration using social science data: indeed, the Hudson Court itself

191 Id. at 598-99 (citations omitted).

192 Id. at 599.

193 The empirical data is provided primarily by WALKER, supra note 188 , at 51 , see $H u d s o n$, 547 U.S. at 599, as well as MiChaEl AVERY ET AL., POLICE MisCONDUCT: LAW AND LiTigation (3d ed. 2005) and NAN ARON, LIBERTY AND JUSTICE FOR ALL: PUBLIC INTEREST LAW IN THE 1980s AND BEYOND (1989). See Hudson, 547 U.S. at 598 (discussing citizen suits as alternative means than exclusion of suing the police). 
engaged in a somewhat (at best) ham-fisted or (at worst) deceitful attempt to use social science to demonstrate its point.

The attempt is ham-fisted because the Court relied on a study that actually came to a conclusion directly opposite from the Court's. The Court cited primarily to Samuel Walker, Taming the System: The Control of Discretion in Criminal Justice 1950-1990. ${ }^{194}$ While the cited page supports the general proposition stated by the Court-that the police have become more professional-Walker actually credits the exclusionary rule for making this happen. ${ }^{195}$ The study that Walker primarily relies upon, Orfield's Exclusionary Rule and Deterrence: An Empirical Study of Chicago Narcotics Officers, ${ }^{196}$ extols the efficacy of exclusionary hearings in training police officers about the contours of the Fourth Amendment. In fact, the deterrent-effect claim, based on the "argu[ment] that the rule did not influence police behavior because prosecutors could not control police procedures . . . [emerged when] the Chicago police and the Illinois State's Attorney's office were forging a much closer working relationship." ${ }^{\text {197 }}$ As a result:

Chicago narcotics officers believe they learn most about changes in the law of search and seizure from in-court experience. The officers' responses to other parts of the survey, particularly those related to training and the lessons learned in court, confirm that in-court experience is not only the most important way of learning about changes in the law, but also the most effective way of learning about the law of search and seizure in general. ${ }^{198}$

If the Court's slapdash use of criminological and social science evidence undermines its assertions about the inefficacy of exclusion, its unsupported assertion about the value of citizen review is equally problematic. The Court states, without citation, that " $[t]$ here is also evidence that the increasing use of various forms of citizen review can enhance police accountability." 199 This empirical assertion could be proved by social science data demonstrating whether citizen review is an effective form of police regulation. Unfortunately, there are reasons to believe that it is not, or at least not in the manner the Court asserts. ${ }^{200}$

194 See Hudson, 547 U.S. at 599.

195 See WALKER, supra note 188 , at 48-51.

196 Myron W. Orfield, Jr., The Exclusionary Rule and Deterrence: An Empirical Study of Chicago Narcotics Officers, 54 U. CHI. L. REV. 1016 (1987).

197 Id. at 1026.

198 Id. at $1036-37$.

199 Hudson, 547 U.S. at 599.

200 See, e.g., Livingston, Citizen Review, supra note 14, at 655 ("complaint processes alone are inadequate even to identify, much less prevent, police misconduct."); Samuel Walker, Citizen Complaints and the Community, in POLICE AND PolicInG: CONTEMPORARY Issues 200 (Dennis Jay Kenney \& Robert P. McNamara eds., 2d ed. 1999) (discussing the wide variety of forms of citizen review, and suggesting that few engage in any direct discipline of the police); Andrew J. Goldsmith, 
My point is not to play "gotcha" with the Supreme Court's footnotes. After all, a more careful marshalling of the empirical data might reveal that the WalkerOrfield conclusions are subject to revision, limitation, or refutation in light of new or additional facts. What is important is that the Court rests its endorsement of a regulatory regime upon criminological and social science data. Its normative, doctrinal conclusions flow from its empirical claims.

The point is that the Court's deterrence argument, now most recently articulated in Herring $v$. United States, ${ }^{201}$ does not propose to end regulation, but to make it more efficient. ${ }^{202}$ In Leon, Hudson, and Herring, the Court believes it has identified a set of sanctions that are more directly deterrent, more transparent and accountable than exclusion. The Court's training-and-experience vision seems to rely upon internal police disciplinary regimes (self-regulation) along with some sort of civilian oversight or tort-based self-help to regulate police investigation. While the Court's arguments in Hudson overplay the role of civilians as well, by disingenuously ignoring the Court-generated difficulties in suing the police, ${ }^{203}$ the Court also declines to learn anything about police training. In fact, the Court knows more about the instruction and effectiveness of police dogs in discovering evidence and establishing probable cause than it does about the training and effectiveness of police officers. ${ }^{204}$

External Review and Self-Regulation: Police Accountability and the Dialectic of Complaints Procedures, in Complaints Against the Police: The Trend to External Review 13, 33-38 (Andrew J. Goldsmith ed., 1991) (discussing citizen review boards and concluding, "In sum, it seems that C[itizen] R[eview] B[oard]s have generally been regarded as inadequate in terms of independence of investigations, their focus on individual grievances, their emphasis on penalties and their lack of credibility with both police and public.").

201129 S. Ct. 695 (2009).

202 See id. at 703 (applicability of exclusionary rule depends upon the sort of knowledge possessed by "a reasonably well trained officer"). While the test announced in Herring, and which relies on Leon, is supposed to be objective, the "circumstance" a trained officer could rely on "frequently include a particular officer's knowledge and experience." Id. The Herring Court suggested that this factor "does not make the test any more subjective than the one for probable cause, which looks to an officer's knowledge and experience." Id. (citing Ornelas v. United States, 517 U.S. 690, 699-700 (1996); Whren v. United States, 517 U.S. 806, 812-13 (1996)). In terms of its comparative analysis, the Court is, of course, correct: the good faith standard is no more subjective than the probable cause standard. But since the probable cause standard is itself subjective, then both are subjective.

${ }^{203}$ See, e.g., City of Canton v. Harris, 489 U.S. 378, 388 (1989) ("the inadequacy of police training may serve as the basis for $\S 1983$ liability only where the failure to train amounts to deliberate indifference to the rights of persons with whom the police come into contact."); Board of Comm'rs of Bryan Cty. v. Brown, 520 U.S. 397, 412 (1997) (discussing standard necessary to support constitutional violation in failure-to-screen case). For an example of an innocent person failing to obtain relief because of an officer's assertion of qualified immunity, see Anderson $v$. Creighton, 483 U.S. 635 (1987) (contours of right must be sufficiently clear that reasonable official would understand that what he is doing violates that right).

${ }^{204}$ Compare Illinois v. Caballes, 543 U.S. 405, 411-12 (2005) (Souter, J., dissenting) ("The infallible [drug-sniffing] dog . . . is a creature of legal fiction .... [T] heir supposed infallibility is belied by judicial opinions describing well-trained animals sniffing and alerting with less than perfect 
The Court's disinterest is particularly worrisome because the Court proposes to replace a tried and tested form of regulation (exclusion) with another (training) about which it knows nothing or next to nothing. That is, the Court rejects exclusion because it has only an indirect deterrent effect, whereas self-regulation by the police and lawsuits or civilian review boards purportedly have a more direct deterrent effect. Yet if the Court has no idea whether police training is done in an effective manner, then there is no reason to assume that training regimes are more effective than (the admittedly marginally deterrent) exclusionary rule. ${ }^{205}$ The only way we can know what works is by finding out more about what training the police receive and how it impacts their ability to engage in self-regulation.

The need for some basis upon which to evaluate training regimes becomes particularly important given the series of perverse incentives the Court has built into recent criminal procedure jurisprudence. For example, if the reasonable police officer can also be a moderately ignorant police officer, then there is a perverse incentive not to learn how the Fourth or Fifth Amendment operates. ${ }^{206}$

If the Court is going to embrace the sort of non-judicial, training-based regulation anticipated by Hudson, Herring, and Leon, then it ought to be sure that it is available and effective. The Court should not just abdicate responsibility for ensuring that the appropriate standards are met without some back-up plan in place. In other words, the marginal effectiveness of the exclusionary rule is better than nothing. If the Court does delegate responsibility for regulating the police to some other body, then it must be prepared for the consequences. If uniformity of police practice is the issue, then possible solutions could include federalized national training standards for police officers or the sort of national licensing regimes and standards strongly resisted by the police; and, on the other hand, attempts to introduce expert testimony demonstrating that the police officers are

accuracy, whether owing to errors by their handlers, the limitations of the dogs themselves, or even the pervasive contamination of currency by cocaine."), with Illinois v. Wardlow, 528 U.S. 119, 122, 124-25 (2000) (permitting search for weapons "because in [the officer's] experience it was common for there to be weapons in the near vicinity of narcotics transactions .... In reviewing the propriety of an officer's conduct, courts do not have available empirical studies dealing with inferences drawn from suspicious behavior, and we cannot reasonably demand scientific certainty from judges or law enforcement officers where none exists. Thus, the determination of reasonable suspicion must be based on commonsense judgments and inferences about human behavior.").

205 Herring, 129 S. Ct. at 703.

206 In the context of the Court's good-faith jurisprudence, critics have noted that to the extent the availability of exclusion turns on a subjective evaluation, "police departments would be encouraged to recruit zealous officers with consistently poor judgment about constitutional limitations, and would be rewarded for leaving their officers ignorant of those limitations." Silas Wasserstrom \& William J. Mertens, The Exclusionary Rule on the Scaffold: But Was It a Fair Trial?, 22 AM. CRIM. L. REV. 85, 118 (1984). Since I believe that the Court has imported an officer-specific subjective evaluation of good faith and probable cause in its totality-of-the-circumstances test in Leon, Hudson, and Herring, I believe the perverse incentive to police ignorance is built into the test. Things were worse in the Fifth Amendment context. See, e.g., Missouri v. Seibert, 542 U.S. 600, 610-11 n.2 (2004) (discussing training materials used to encourage police to engage in an end run around the Miranda warnings). See also Weisselberg, supra note 81, at 110, 132-39. 
insufficiently well trained to make the sort of totality-of-the-circumstances judgments endorsed in Leon, Ornelas, Hudson, and Herring.

Licensing is important because, for training to be effective, it must continue outside the academy as well as inside. Accordingly, even if the Court could assure itself that the type of training provided by the various disparate police academies were sufficiently effective and uniform (and it has not), it would also need to ensure that training and testing continued throughout the career of an officer. Continued training is needed to make certain that they remain competent in the uniform, national application of probable cause in evaluating evidence of suspicious behavior through the lens of their training and experience.

The sociological data misrepresented by the Court in Hudson goes straight to the heart of the available evidence on police instruction. The real data suggests that the courts themselves are effective, if intermittent, teachers. Put simply, in order to reject Mapp's exclusionary rule in the name of deterrence, the Court miscites an article that supports an alternate, anti-deterrence argument: that the government (in the form of the judiciary) is "the potent, the omnipresent teacher," and that the judicial branch can train police using the exclusionary rule, thereby providing instruction not only for the general public, but for the other branches of government. ${ }^{207}$

In the absence of an exclusionary rule, or in the presence of a much circumscribed one, criminal procedure must become more aware of the sociological and criminological data. Proceduralists must take a much closer look at the real world of policing, for the reasons adduced by Weisberg and Sklansky. First, that when thinking about the legal system, realism, as Weisberg argues, is essential: it should be our ethical imperative. Second, because for the reasons adduced by Sklansky, we must develop an adequate account of the institutional structure of the police and its place in our understandings of state democratic accountability.

\section{CONCLUSION}

Both Leon and Hudson propose training as a form of regulation. Training operates as a form of categorical pre-clearance, but also provides opportunities for retrospective review. Leon addresses one feature of training and Hudson the other. Leon emphasizes the front-end, pre-clearance aspect, claiming the police are better trained now than thirty years ago; while this claim is also reflected in Hudson, the latter case emphasizes the manner in which training interacts with internal discipline or citizen review to promote a well-regulated, professional police force. But the Court makes no real effort to ascertain either the level of training the police receive or whether the training equips the police to work within the constraints of the Fourth Amendment.

207 Mapp v. Ohio, 367 U.S. 643, 659 (1961). 
Both training and the various remedies proposed by the Court in Hudson depend upon the sort of institutional analysis advocated by Weisberg and Sklansky. The Court uses the interrelation of deterrence and the institutional organization of the police force to justify delegating scrutiny to private initiative (tort law) or some administrative process, whether through departmental discipline or a citizen review board. ${ }^{208}$ Yet it is not clear that the police operate in the manner assumed by the Court, particularly as it does not make clear whether it regards the police as managerial experts, or craftsmen, or lawless, or something else. These are issues that social science and criminology are beginning to address, and both disciplines can serve to illuminate criminal procedure scholarship's normative and evaluative debates over how best to regulate the police.

${ }^{208}$ Hudson v. Michigan, 547 U.S. 586, 599 (2006). 
